SJ Quinney College of Law, University of Utah Utah Law Digital Commons

$2-2021$

Social Norms in Fourth Amendment Law

Matthew Tokson

Ari Ezra Waldman

Follow this and additional works at: https://dc.law.utah.edu/scholarship

Part of the Fourth Amendment Commons 


\title{
SOCIAL NORMS IN FOURTH AMENDMENT LAW
}

\author{
Matthew Tokson ${ }^{\dagger} \&$ Ari Ezra Waldman
}

Courts often look to existing social norms to resolve difficult questions in Fourth Amendment law. In theory, these norms can provide an objective basis for courts' constitutional decisions, grounding Fourth Amendment law in familiar societal attitudes and beliefs. In reality, however, social norms can shift rapidly, are constantly being contested, and frequently reflect outmoded and discriminatory concepts. This Article draws on contemporary sociological literatures on norms and technology to reveal how courts' reliance on norms leads to several identifiable errors in Fourth Amendment jurisprudence.

Courts assessing social norms generally adopt what we call the closure principle, or the idea that social norms can be permanently settled. Meanwhile, courts confronting new technologies often adopt the nonintervention principle, or the idea that courts should refrain from addressing the Fourth Amendment implications of new surveillance practices until the relevant social norms become clear. Both of these approaches are flawed, and they have substantial negative effects for equality and privacy. By adopting norms perceived as closed, courts may embed antiquated norms in Fourth Amendment law-norms that often involve discrimination on the basis of race, gender, or class. By declining to intervene when norms are undeveloped, courts cede power over norm creation to companies that design new technologies based on data-extractive business models. Further, judicial norm-reliance and nonintervention facilitate surveillance creep, where familiar data-gathering infrastructures are used for new types of surveillance and monitoring.

This Article provides, for the first time, a full, critical account of the

\footnotetext{
† Professor of Law, S.J. Quinney College of Law.

¥ Professor of Law and Computer Science, Northeastern University School of Law and Khoury College of Computer Sciences. The authors share credit and responsibility for this Article equally. Our thanks to Anita Allen, Shima Baradaran Baughman, Danielle Keats Citron, Julie E. Cohen, David Gray, Cathy Hwang, Daniel Medwed, Ed Purcell, and Jeff Schwartz. Special thanks to Luis Felipe Escobedo, Margaret Foster, and George LaBonty for excellent research assistance.
} 
role of social norms in Fourth Amendment law. It details and challenges courts' reliance on social norms in virtually every aspect of Fourth Amendment jurisprudence. And it explores potential new directions for Fourth Amendment law, including novel doctrinal paradigms, different conceptions of stare decisis in the Fourth Amendment context, and alternative institutional regimes for regulating government surveillance. 


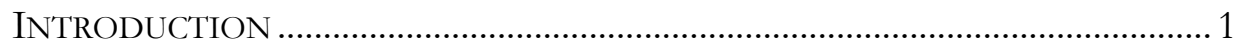

I. SOCIAL NORMS AND THE FOURTH AMENDMENT …................................. 6

A. The Conventional Account of Social Norms ...................................... 7

B. The Jurisprudence of Social Norms................................................... 9

C. Contested Social Norms and Judicial Nonintervention....................12

II. LAW AND THE CONSTRUCTION OF SOCIAL NORMS ...............................16

A. Law's Influence on Social Norms .......................................................16

B. Law and the Construction of Technology ……................................22

III. Challenging Norm Reliance and Judicial Nonintervention

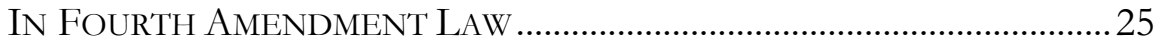

A. The Problem of Discriminatory Norms..............................................26

1. Racially Discriminatory Norms..............................................27

2. Gender-Discriminatory Norms …………............................29

3. Class-Discriminatory Norms ....................................................31

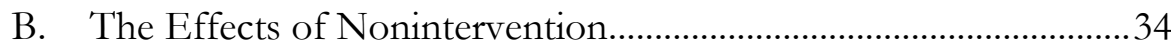

1. Nonintervention and Government Surveillance ..................34

2. Informational Capitalism and Anti-Privacy Norms............37

C. Surveillance Creep ……………………………....................................... 41

IV. New Directions For LAW AND SOCIAL NormS .................................45

A. New Fourth Amendment Paradigms....................................................46

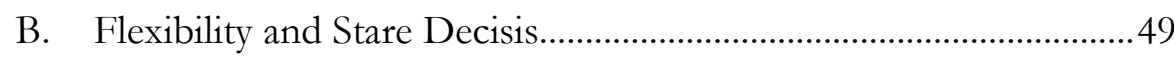

C. Alternative Institutional Structures ....................................................51

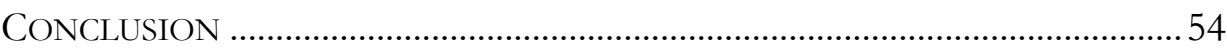




\section{INTRODUCTION}

Social norms play a central role in Fourth Amendment law. The Supreme Court has emphasized the "great significance given to widely shared social expectations" and "social practice," which can act as "a foundation of Fourth Amendment rights." "Indeed, for Fourth Amendment purposes, our "[e]xpectations of privacy are established by general social norms."2 Courts' assessments of norms drive outcomes in every aspect of Fourth Amendment law, including searches, ${ }^{3}$ seizures, ${ }^{4}$ reasonable suspicion, ${ }^{5}$ consent to search, ${ }^{6}$ and special needs inspections performed without probable cause. ${ }^{7}$

Social norms are the informal standards of conduct or widely accepted behaviors that characterize a given community. ${ }^{8}$ As such, they can give courts an ostensibly objective basis for their Fourth Amendment decisions,

${ }^{1}$ Georgia v. Randolph, 547 U.S. 103, 111, 113 (2006). See also, e.g., Rakas v. Illinois, 439 U.S. 128, $143 \mathrm{n} .12$ (1978) (stating that reasonable expectations of privacy "must have a source outside of the Fourth Amendment," one grounded either in property ownership or in "understandings that are recognized and permitted by society").

2 Robbins v. California, 453 U.S. 420, 428 (1981) (plurality op.), overruled on other grounds by United States v. Ross, 456 U.S. 798 (1982). See also, e.g., Florida v. Jardines, 569 U.S. 1, 9 (2013) (basing its holding on the "background social norms" that govern approaches to the front door of a home).

${ }^{3}$ E.g., Minnesota v. Olson, 495 U.S. 91, 98-99 (1990).

${ }^{4}$ E.g., United States v. Drayton, 536 U.S. 194, 205-06 (2002).

${ }^{5}$ E.g., Illinois v. Wardlow, 528 U.S. 119, 124-25 (2000).

${ }^{6}$ E.g., Georgia v. Randolph, 547 U.S. 103, 111 (2006).

${ }^{7}$ E.g., Camara v. Municipal Court, 387 U.S. 523, 535-36 (1967).

8 Sanford Labovitz \& Robert Hagedorn, Measuring Social Norms, 16 PACIFIC SoC. REV. 183, 184 (1973) (stating that social norms are standards of conduct that "should or should not be followed"). See also C.A. Harwell Wells, The End of the Affair? Anti-Dueling Laws and Social Norms in Antebellum America, 54 VAND. L. REV. 1805, 1809 (2001) (providing that norms are activities "society holds that people should do"); ERIC POSNER, LAW AND SOCIAL NORMS 7 (2000) (positing that social norms are imitative behavioral patterns grounded in cooperative relationships). Most legal scholars tie social norms to the prospect of informal social sanctions. See Richard McAdams, The Origin, Development, and Regulation of Norms, 96 MiCH. L. REV. 338, 340 (1999) (stating that norms are "informal social regularities that individuals feel obligated to follow because of an internalized sense of duty, because of fear of external nonlegal sanctions, or both.”); Robert Ellickson, Law and Economics Discovers Social Norms, 27 J. LEGAL STUD. 537, 549 n.58 (1998) (“[A] norm is a rule supported by a pattern of informal sanctions."). 
grounding their rulings in longstanding societal practices that people know and understand. Courts relying on social norms do not, in other words, start from scratch - they identify and adopt existing societal attitudes towards surveillance or police behavior and use those attitudes to chart the course of constitutional law. 'The conventional account of social norms in Fourth Amendment law largely supports their use whenever feasible. ${ }^{10}$

This Article challenges the conventional account and gives a fuller and more nuanced picture of courts' reliance on social norms in Fourth Amendment law. It shows the dangers of the Fourth Amendment's current course, which ultimately privileges the data-extractive interests of technology companies and government entities over individual rights.

Currently, most courts assessing social norms approach them in one of two ways. When courts perceive that relevant social norms are stable, they adopt what we are calling the closure principle, or the idea that social norms can become more or less settled. In these situations, courts frequently apply social norms to resolve Fourth Amendment cases. When courts perceive that relevant social norms have not yet stabilized, they adopt what we call the nonintervention principle, or the idea that courts should decline to weigh in on new surveillance practices until the relevant social norms become clear. In these situations, courts generally refrain from addressing the Fourth Amendment implications of new technologies whenever possible. These approaches are exemplified by the Supreme Court's decision in City of Ontario v. Quon, ${ }^{11}$ which involved the warrantless inspection of the text messages of government employees. ${ }^{12}$ The Court explicitly refused to consider "farreaching" issues raised by new surveillance-enhancing technologies, arguing that the judiciary "risks error by elaborating too fully on the Fourth Amendment implications of emerging technology before its role in society has become clear."13

This Article's analysis, drawing on the contemporary sociological literature on norms and technology, reveals the flaws inherent in courts' current approaches. Social norms are neither immutable nor independent of sociolegal institutions. They are constantly being contested, and even

\footnotetext{
9 See infra Part I.B.

10 See infra Part I.A.

11560 U.S. 746 (2010).

${ }^{12} \mathrm{Id}$. at 750 .

${ }^{13} I d$. at 759 .
} 
seemingly stable norms are susceptible to gradual or rapid change. ${ }^{14}$ Moreover, law has the capacity to alter social norms by expressing values that influence attitudes and behavior. The expressive force of early laws limiting where people could smoke cigarettes eventually altered social norms around smoking, providing the impetus for greater restrictions. ${ }^{15}$ Anti-sodomy laws, though largely unenforced, shaped social norms by stigmatizing gay peopleand their repeal by the Supreme Court in 2003 helped to promote norms favoring equality and acceptance. ${ }^{16}$ In neither case were existing social norms "closed," and law played a vital role in shaping and improving norms going forward.

Law also generates and influences norms surrounding new technologies. Technologies are themselves socially constructed, as users adapt them to existing social structures in unpredictable ways and shape their future development. The car, the telephone, the internet, the smartphone, and countless apps and other software have been shaped in profound ways by law and social processes. ${ }^{17}$

Leveraging these insights, we identify substantial flaws in Fourth Amendment paradigms that rely on existing social norms or wait for them to settle before intervening. First, courts adopting existing social norms can entrench ideas that are outmoded and discriminatory. ${ }^{18}$ Norms regarding police-citizen interactions, which encourage voluntary interaction with police officers and compliance with police demands, can have racially discriminatory impacts. ${ }^{19}$ Norms involving domestic privacy and appropriate social behavior may have disparate gender impacts and can make it more

14 See infra Part II.A.

15 See Dan M. Kahan, Gentle Nudges vs. Hard Shoves: Solving the Sticky Norms Problem, 67 U. CHI. L. REV. 607, 611 (2000) (discussing how law's incremental approach to regulating cigarettes effectively changed norms around smoking).

16 See infra Part II.A; Nan D. Hunter, Sexual Orientation and the Paradox of Heightened Scrutiny, 102 MiCH. L. REV. 1528, 1536 (2004); Christopher R. Leslie, Creating Criminals: The Injuries Inflicted by "Unenforced" Sodomy Laws, 35 HARV. C.R.-C.L. L. REV. 103 (2000); William N. Eskridge, Jr., Law and the Construction of the Closet: American Regulation of Same-Sex Intimacy, 1880-1946, 82 IowA L. REV. 1007, 1069 (1997); Janet E. Halley, Reasoning About Sodomy: Act and Identity in and After Bowers v. Hardwick, 79 VA. L. REV. 1721, 1729 (1993). See also Jason Mazzone, When Courts Speak: Social Capital and Law's Expressive Function, 49 SYRACUSE L. REV. 1039, 1041 (1999) (suggesting sodomy laws are paradigms of law's expressive value).

17 See infra Part II.B.

18 See infra Part III.A.

19 See Wardlow, 528 U.S. at 124; Drayton, 536 U.S. at 203-206. 
difficult for authorities to prevent domestic abuse. ${ }^{20}$ And norms surrounding workplace behavior and residential buildings can discriminate against poorer citizens or those with unstable employment situations. ${ }^{21}$ In several important cases, courts have based their Fourth Amendment rulings on dominant social practices without asking why those practices exist. In doing so, they have often embedded discriminatory norms into constitutional law.

Second, courts that decline to intervene until norms have settled encourage unfettered government surveillance and cede norm creation to data-extractive technology companies. Proponents of nonintervention justify judicial neutrality by suggesting that sociotechnical norms should settle organically, as users and designs adapt to each other, without the judiciary putting a thumb on the scale. ${ }^{22}$ But a thumb is already on the scale. In practice, sociotechnical norms are not organically generated by autonomous individuals. They are filtered through the economic interests of the most powerful actors in the field: the companies that design those technologies. Their business models are based on the idea that data is profit, or what scholars have called "surveillance capitalism" or "informational capitalism."23 These companies carefully design and market products to encourage sharing, to nudge consumer behavior toward disclosure, and to desensitize users to the potential harms of surveillance. These processes influence the development of sociotechnical norms, pushing them toward greater acceptance of surveillance and the devaluation of privacy. By declining to get involved in the business of norm generation, courts allow sociotechnical norms to develop in ways that align with data-extractive interests.

Further, if courts wait for sociotechnical norms to stabilize before regulating the government's use of new surveillance technologies, they will allow many forms of surveillance to go unchecked. ${ }^{24}$ Social norms rarely

20 See Randolph, 547 U.S. at 111-13.

21 See INS v. Delgado, 466 U.S. 210, 218 (1984). Compare Collins v. Virginia, 138 S. Ct. 1663, 1670 (2018) (holding that police officers could not enter the curtilage of a home without a warrant), with United States v. Nohara, 3 F.3d 1239, 1241 (9th Cir. 1993) (holding that a tenant had no reasonable expectation of privacy in an apartment hallway against police presence in his hallway regardless of whether the police were trespassing).

22 E.g., Quon v. City of Ontario, 560 U.S. 747, 759 (2010).

23 See Shoshana Zuboff, The Age of Surveillance Capitalism (2019); Julie Cohen, BETWEEN TRUTH AND POWER (2019).

${ }^{24}$ Cf. Orin S. Kerr, An Equilibrium-Adjustment Theory of the Fourth Amendment, 125 HARV. L. REV. 476, 526 (2011) (arguing that " $[t]$ he Supreme Court should generally decline to review how the Fourth Amendment applies to a new technology until the technology, its use, and 
definitively settle, and it may take several years or decades for technologies and norms to stabilize even partially. ${ }^{25}$ Until they do, the government will have free reign to surveil citizens - and the cycle will begin anew with each new form of technology.

Finally, judicial nonintervention facilitates "surveillance creep," where existing data-gathering technologies are used for new types of surveillance and information collection. For instance, the establishment of traffic cameras on public streets makes it easier for the government to gather facial recognition data on passersby, because the mechanism for this surveillance is already in place. ${ }^{26}$ Surveillance creep can also have a powerful impact on social norms around technology because of its ability to normalize new surveillance as merely an extension of existing practices. Courts have been vulnerable to this effect, often treating invasive new surveillance practices as benign because they use familiar surveillance infrastructures. ${ }^{27}$

Norms may still have a place in Fourth Amendment jurisprudence, despite these serious concerns. But rather than simply adopting norms they perceive are settled, courts must question whether those norms are justifiable. And courts that choose not to intervene when confronted with new data-gathering technologies should appreciate the pro-surveillance effects of nonintervention.

Based on our analysis, we explore new directions for Fourth Amendment law that can allow courts to intervene effectively in novel cases and avoid reliance on existing norms. Alternative paradigms of Fourth Amendment law could encourage courts to look ahead at the effects of surveillance rather than looking back at outmoded norms. Courts could embed flexibility in Fourth Amendment law by expressly limiting the force of stare decisis for decisions addressing new technologies, where rapid contextual change is the rule rather than the exception. Finally, alternative institutional arrangements for regulating government surveillance could be adopted, with legislatures and administrative agencies working alongside

its societal implications have stabilized.").

25 See infra Part III.B.1.

26 See infra Part III.C.

27 See United States v. White, 401 U.S. 745, 752 (1971) (holding that undercover agents could record conversations inside a suspect's home on the basis of prior cases permitting agents without recording devices); United States v. Forrester, 512 F.3d 500, 505 (9th Cir. 2008) (ruling that agents could use a device to monitor an individual's internet and email traffic based on a prior case permitting the use of a similar device to track dialed phone numbers). 
courts to comprehensively address new surveillance technologies. Together, these novel approaches can help realize the promise of the Fourth Amendment as a shield against government overreach in an era of rapidly evolving surveillance technologies.

Our concerns about judicial adoption of the closure and nonintervention principles are not strictly academic. Their continued use in Fourth Amendment law poses particular risks today. State and local governments have recently deployed industry-designed contact tracing apps to monitor Covid-19 outbreaks, with little infrastructure in place to guard against government use of the apps' data for surveillance purposes. ${ }^{28}$ Cities are repurposing streetlight traffic cameras to surveil protesters and other law enforcement targets. ${ }^{29}$ Moreover, at a time when many institutions are finally reckoning with the nation's legacies of racism and sexism, Fourth Amendment law's continued embrace of antiquated norms is ripe for reform.

The Article proceeds in four Parts. Part I surveys the conventional theoretical account of social norms in Fourth Amendment law. It then describes several cases across many areas that expressly rely on such norms to determine the scope and content of the Fourth Amendment. Part II examines the sociological literature on norms and the law's role in shaping them. It describes the phenomenon of social construction of technology and defines and critiques the closure principle. Part III challenges the widespread use of social norms in Fourth Amendment law. It evaluates the discriminatory effects of existing norms used in several prominent cases and analyzes the legal and social harms of judicial nonintervention in contexts involving new technologies. Part IV explores potential new directions for Fourth Amendment law that rely less heavily on social norms. It sets out several alternative approaches, including new doctrinal approaches, more flexible conceptions of stare decisis in cases involving new technologies, and unconventional institutional regimes for regulating government surveillance.

\section{SOCIAL NORMS AND THE FOURTH AMENDMENT}

The following sections review the conventional account of the role of social norms in Fourth Amendment law. They examine some of the most prominent cases that rely on norms to determine the scope or application of

\footnotetext{
28 See infra note 251 and accompanying text.

29 See infra note 249 and accompanying text.
} 
the Fourth Amendment. They also describe the common judicial practice of declining to intervene when norms surrounding a new technology are still in flux. As this Part demonstrates, when courts perceive that norms are stable, they generally adopt the closure principle; when courts perceive that norms are unsettled, they generally adopt the nonintervention principle.

\section{A. The Conventional Account of Social Norms}

The conventional wisdom in Fourth Amendment law largely endorses the use of social norms whenever possible. When identifiable social norms exist, courts can draw on them as an objective, external basis for Fourth Amendment doctrine. ${ }^{30}$ Social norms sometimes may be difficult to discern, but correctly identified norms offer useful guidance in an otherwise difficult area of law. ${ }^{31}$

Legally relevant social norms are generally thought to arise from social practices that become accepted, repeated, and routinized over time. ${ }^{32}$ When people consider a prevalent social practice to be justified and beneficial, it gains a normative edge, and may be associated with social pressures to comply and informal sanctions for non-compliance. ${ }^{33}$ These social norms may eventually be embedded as law. ${ }^{34}$ In the commercial law context, this often takes the form of incorporating longstanding customs into the common law of trade and contract. ${ }^{35} \mathrm{~A}$ similar process can be observed in Fourth Amendment law, as norms of privacy and law enforcement practice

\footnotetext{
30 See, e.g., Georgia v. Randolph, 547 U.S. 103, 111, 113 (2006) (stating that the Court gives "great significance ... to widely shared social expectations" and "social practice[s]," which can act as "a foundation of Fourth Amendment rights."); Rakas v. Illinois, 439 U.S. 128, 143 n.12 (1978) (noting that reasonable expectations of privacy "must have a source outside of the Fourth Amendment," one grounded either in property ownership or in social norms, defined as "understandings that are recognized and permitted by society."); Jed Rubenfeld, The End of Privacy, 61 STAN. L. REV. 101, 107 (2008); William C. Heffernan, Fourth Amendment Privacy Interests, 92 J. CRIM. L. \& CRIMINOLOGY 1, 37 (2001).

${ }^{31}$ Heffernan, supra note 30, at 37.

32 Michael J. Zydney Mannheimer, Decentralizing Fourth Amendment Search Doctrine, 107 KY. L.J. 169, 195 (2018).

${ }^{33}$ Id. at 196; Heffernan, supra note 30, at 43-44.

34 Mannheimer, supra note 32, at 197-99; see also United States v. White, 401 U.S. 745, 786 (1971) (Harlan, J., dissenting) ("Our expectations, and the risks we assume, are in large part reflections of laws that translate into rules the customs and values of the past and present."). 35 Mannheimer, supra note 32, at 197-99.
} 
are gradually codified as constitutional law. ${ }^{36}$

Social norms may be difficult to identify, and the Supreme Court has given little guidance on how to assess norms for Fourth Amendment purposes. ${ }^{37}$ Moreover, the Court's assessments of norms can be criticized as inaccurate or biased in favor of the government. ${ }^{38}$ But at least where the Justices perceive that norms are settled, the Court has frequently used them to determine the contours of Fourth Amendment law. ${ }^{39}$

By contrast, in cases involving new technologies where social norms and practices have not yet reached maturity, judges and scholars have argued for caution. ${ }^{40}$ In these situations, the conventional account suggests it may be more prudent for courts to avoid deciding Fourth Amendment questions whenever possible. ${ }^{41}$ As the Supreme Court has warned, "[t]he judiciary risks error by elaborating too fully on the Fourth Amendment implications of emerging technology before its role in society has become clear." ${ }^{42}$ Caution may be especially justified, according to this account, when a technology and the social practices surrounding it continue to change rapidly. ${ }^{43}$ In contexts where "it is uncertain how ... norms, and the law's treatment of them, will evolve," courts may avoid ruling broadly on Fourth Amendment issues and allow social norms and practices to settle before intervening. ${ }^{44}$ Only Justice Scalia disagreed with this account of the role of norms in technology cases, and even he, in other contexts, expressly endorsed the use of social norms in setting the boundaries of Fourth Amendment protection. ${ }^{45}$

\footnotetext{
${ }^{36}$ Rubenfeld, supra note 30, at 107; Heffernan, supra note 30, at 37.

${ }^{37}$ Heffernan, supra note 30, at 37.

${ }^{38}$ Blitz, supra note Error! Bookmark not defined., at 1415.

39 See City of Ontario v. Quon, 560 U.S. 746, 759 (2010) (describing how the Court in Katr. used its knowledge and experience of telephone practices to identify a reasonable expectation of privacy in phone calls); Rakas, 439 U.S. at 143 n.12 (1978) ("Legitimation of expectations of privacy by law must have a source outside of the Fourth Amendment, either by reference to concepts of real or personal property law or to understandings that are recognized and permitted by society."); Randolph, 547 U.S. at 111-113 (noting the central importance of social understandings and practices to Fourth Amendment consent doctrines); Kerr, supra note 24 , at 539.

${ }^{40}$ Quon, 560 U.S. at 759; Kerr, supra note 24, at 540.

41 See supra note 40.

42 Quon, 560 U.S. at 759.

${ }^{43} I d$. ("Rapid changes in the dynamics of communication and information transmission are evident not just in the technology itself but in what society accepts as proper behavior.’).

${ }^{44} I d$.

${ }^{45}$ Id. at 768 (Scalia, J., concurring in part and concurring in the judgment); Jardines, 569 U.S.
} 


\section{B. The Jurisprudence of Social Norms}

Courts decide Fourth Amendment cases using a variety of doctrines, precedents, and policy considerations. Social norms alone do not dictate every Fourth Amendment outcome. However, when social norms or practices are relevant to the issue at hand, courts frequently rely on them to determine the course of Fourth Amendment law. This happens most often when courts perceive those norms to be settled, stable, or "closed".

The Supreme Court has itself characterized social norms as an objective basis for the Fourth Amendment's scope. A Fourth Amendment search occurs when government officials violate a reasonable expectation of privacy. ${ }^{46}$ The Court has stated that reasonable expectations of privacy "must have a source outside of the Fourth Amendment," one grounded either in property ownership or in social norms, defined as "understandings that are recognized and permitted by society." "In another case, a plurality of Justices stated directly that "[e]xpectations of privacy are established by general social norms." 48 Lower courts and leading Fourth Amendment treatises have echoed this statement, expressly tying the Fourth Amendment to assessments of social norms. ${ }^{49}$

The Supreme Court, for example, has drawn a line between houseguests

at 9 ("Here, the background social norms that invite a visitor to the front door do not invite him there to conduct a search.").

${ }^{46}$ Katz v. United States, 389 U.S. 347, 360 (1967) (Harlan, J., concurring). The Supreme Court has recently adopted a separate test that also finds a Fourth Amendment search when a government official physically intrudes on property for the purpose of gathering information. See Florida v. Jardines, 569 U.S. 1, 7-10 (2013); United States v. Jones, 565 U.S. 400, 404-06 (2012). In practice, this has added little to the Katz test, and the Supreme Court cases where it has been employed may have reached the same outcome under Katr. See Jardines, 569 U.S. at 12-16 (Kagan, J., concurring); Jones, 565 U.S. at 418-31 (Alito, J., concurring in the judgment).

${ }^{47}$ Rakas v. Illinois, 439 U.S. 128, 143 n.12 (1978).

${ }^{48}$ Robbins v. California, 453 U.S. 420, 428 (1981) (plurality op.), overruled by United States v. Ross, 456 U.S. 798 (1982).

49 See, e.g., Raynor v. State, No. 69, 2014 WL 4216019, at*6 (Md. Aug. 27, 2014) (“[C]ommon experience and social norms bear upon our assessment of whether one has an objectively reasonable expectation of privacy in a particular item or place. Expectations of privacy are established by general social norms.") (internal quotations and citations omitted); 1 WAYNE R. LAFAVE, SEARCH AND SEIZURE \2.1(d), at 587 (5th ed. 2012) (“ $\Pi$ t is necessary to look to the customs and values of the past and present, the structure of society, the patterns of interaction, [and] the web of norms and values.") (internal quotations and citations omitted). 
with privacy rights and houseguests without such rights based on its assessments of social norms. In Minnesota $v$. Olson, ${ }^{50}$ the Court concluded that an overnight houseguest could challenge a police search of his friend's house. ${ }^{51}$ The opinion engaged in a lengthy analysis of established social customs and practices, ultimately concluding that homeowners hosting their friends for an overnight visit typically grant their guests a measure of control and privacy within their home. ${ }^{52}$ The norms are different, however, for shorter duration guests, and the Fourth Amendment accordingly offers them less protection. ${ }^{53}$ The Court's detailed analyses of the social roles of host and houseguest provided the foundation for the these Fourth Amendment rulings. This pattern recurs in numerous Fourth Amendment scope cases. ${ }^{54}$

50495 U.S. 91 (1990).

51 Id. at 93.

52 Among other things, the Court stated that:

Staying overnight in another's home is a longstanding social custom that serves functions recognized as valuable by society. We stay in others' homes when we travel to a strange city for business or pleasure, when we visit our parents, children, or more distant relatives out of town, when we are in between jobs or homes, or when we house-sit for a friend ... It is unlikely that the guest will be confined to a restricted area of the house; and when the host is away or asleep, the guest will have a measure of control over the premises ... The point is that hosts will more likely than not respect the privacy interests of their guests, who are entitled to a legitimate expectation of privacy despite the fact that they have no legal interest in the premises and do not have the legal authority to determine who may or may not enter the household.

Id. at 98-99.

53 See Minnesota v. Carter, 525 U.S. 83, 90-91 (1998). The Carter Court concluded that there was no identifiable social custom or norm that would extend the full protections of the home to a person who was merely present for a short time. Id. at 90-91.

${ }^{54}$ In Byrd v. United States, 138 S. Ct. 1518, 1529 (2018), the Court held that a driver who borrowed a rented car with the permission of the renter had a reasonable expectation of privacy in the car because social norms dictate that a friend might use a car for a variety of legitimate reasons. Id at 1527-29. Social norms also play a central role in the leading case applying trespass concepts to determine the Fourth Amendment's scope. For instance, Florida v. Jardines, 569 U.S. 1, 8-9, 11-12 (2013), relied on the "background social norms that invite a visitor to the front door" to hold that police officers violated a defendant's Fourth Amendment rights when they approached his front door with a drug-sniffing dog. See also, e.g., Bond v. United States, 529 U.S. 334 (2000) (determining that an officer's squeezing and manipulating the carry-on bag of a bus passenger went beyond socially acceptable practices and was therefore a Fourth Amendment search); Rawlings v. Kentucky, 448 U.S. 98, 100, 105 (holding that a defendant had no Fourth Amendment right in another's handbag where he had not known her well prior to the search); Katz v. United States, 389 U.S. 347, 352 (basing its holding on "the vital role that the public telephone has come to play in private 
Likewise, in Fourth Amendment consent cases, the Court gives "great significance ... to widely shared social expectations" and "social practice[s]," which can act as "a foundation of Fourth Amendment rights." 55 Thus a police officer can enter a house with the permission of only one co-tenant, because "customary social usage" permits such entry. ${ }^{56}$ But if another tenant is present and objects, "commonly held understanding[s] about the authority that co-inhabitants may exercise" dictate that the officer cannot enter. ${ }^{57}$ Entering a house over the objection of a tenant would violate social norms of propriety. ${ }^{58}$

A similar reliance on social norms occurs in cases involving nonphysical seizures. ${ }^{59}$ The norms that govern public buses, workplaces, and interactions with police officers often determine whether a person has been seized or not under the Fourth Amendment. ${ }^{60}$

Finally, courts assessing the reasonableness of searches and seizures often rely on social norms. ${ }^{61}$ The Supreme Court has implicitly endorsed this practice, noting that the reasonableness of a stop-and-frisk "must be based on commonsense judgments and inferences about human behavior." ${ }^{62}$ Social norms and practices play a pivotal role in other reasonableness cases as well, especially cases involving administrative searches or suspicionless drug testing in state-controlled settings. ${ }^{63}$

communication.”).

${ }^{55}$ Georgia v. Randolph, 547 U.S. 103, 111, 113 (2006).

${ }^{56}$ Fernandez v. California, 571 U.S. 292, 303 (2014).

${ }^{57}$ Randolph, 547 U.S. at 111-13.

${ }^{58}$ Id. at $113-14$.

59 The typical Fourth Amendment seizure involves the arrest or physical detention of a suspect. E.g., California v. Hodari D., 499 U.S. 621, 626 (1991).

60 E.g., United States v. Drayton, 536 U.S. 194, 197-98, 203-5 (2002) (relying on the prevailing norm of cooperation with police officers to conclude that a passenger on a Greyhound bus could have declined officers' requests to search his bag and pat down his clothes); INS v. Delgado, 466 U.S. 210, 212, 218 (1984) (relying on norms of the factory floor to conclude that immigration agents did not seize factory workers when several agents blocked the factory exits while others, wearing badges and visible guns, questioned workers). ${ }^{61}$ This practice arguably comports with the text and history of the Amendment itself. See AKHIL REED AMAR, AMERICA's UNWRITTEN CONSTITUTION 303 (2012) ("The word 'unreasonable' in the Fourth Amendment also authorizes interpreters to take evolving social norms into account.").

${ }^{62}$ Illinois $v$. Wardlow, 528 U.S. 119, 125 (2000).

${ }^{63}$ For instance, social norms appear to shape the outcomes of the Supreme Court's drugtesting cases. Compare Ferguson v. City of Charleston, 532 U.S. 67, 78 \& n.14 (2001) (holding 
The Supreme Court, and courts in general, do not overtly assess social norms in every Fourth Amendment case. But when norms are relevant and clear, courts often use them in shaping Fourth Amendment law. This process is complicated, however, when courts attempt to address new technologies that are not yet associated with established social norms or practices.

\section{Contested Social Norms and Judicial Nonintervention}

New technologies pose some of the most difficult issues in Fourth Amendment law. ${ }^{64}$ Modern devices and services also present a variety of complex issues involving social norms and practices. ${ }^{65}$ For instance, whether information disclosed to dating apps, smart-home devices, social media, or internet service providers is protected by the Fourth Amendment may depend on the social customs surrounding those technologies. ${ }^{66}$ In the face of these complexities, courts have often struggled to effectively apply the Fourth Amendment to new technological contexts. ${ }^{67}$

When courts perceive that social norms surrounding a technology have begun to harden, however, they have eagerly turned to them as objective bases for their decisions. ${ }^{68}$ For example, in Katz v. United States, ${ }^{69}$ the Supreme Court ruled that the Fourth Amendment prohibited the warrantless recording of telephone calls, with the majority emphasizing "the vital role that the public telephone has come to play in private communication." ${ }^{70} \mathrm{By}$

it was not reasonable for a state hospital to disclose pregnant women's drug test results to the police, partly because doing so violates the traditional understanding that the results of diagnostic tests will not be shared with nonmedical personnel), with Vernonia School District 47J v. Acton, 515 U.S. 646, 665 (1995) (holding that it was reasonable to require high school athletes to take random drug tests, in part because athletes were role models in the school).

${ }^{64}$ Daphna Renan, The Fourth Amendment as Administrative Governance, 68 STAN. L. REV. 1039 (2016); Kerr, supra note 24, at 486; DAVID GRAY, THE FOURTH AMENDMENT IN AN AGE OF SURVEILLANCE (2017).

65 See Matthew Tokson, The Normative Fourth Amendment, 104 MinN. L. REV. 741 (2019).

66 See Matthew Tokson, Inescapable Surveillance, 105 CORNELL L. REV. (forthcoming 2021)

(noting that the ubiquity and social importance of these services and devices may determine whether they are protected by the Fourth Amendment under current law).

${ }^{67}$ E.g., Olmstead v. United States, 277 U.S. 438 (1928); United States v. Graham (Graham II), 824 F.3d 421, 429 (4th Cir. 2016) (en banc); United States v. Forrester, 512 F.3d 500 (9th Cir. 2008).

68 See supra note 40.

69389 U.S. 347 (1967).

${ }^{70} \mathrm{Id}$. at 352 . 
the time Katz, was decided in 1967, it was clear that a person who entered a telephone booth, shut its door, and paid to use the phone was entitled to privacy - if not against visual observation, then against "the uninvited ear.",71 The Court's assessment came several decades after the telephone was popularized, when the social role of the telephone was relatively stable and mature. $^{72}$

In recent years, the Court has made similar assessments about the ubiquity and social role of cell phones. Riley v. California, ${ }^{73}$ which ruled that cell phones could not be searched incident to arrest, was based on the Court's findings that most people depend on their cell phones and carry them wherever they go, sometimes even in the shower. ${ }^{74}$ Moreover, given the way people use cell phones-to send personal communications, store photographs, browse the internet, set their personal schedules, download an average of 33 apps per user-they tend to contain the privacies of life. ${ }^{75}$ The Court relied on a similar analysis in Carpenter $v$. United States ${ }^{76}$ to hold that the Fourth Amendment required police to obtain a warrant before tracking cell phone signals. $^{77}$

However, in cases involving new technologies around which social practices were still indeterminate, the Court has taken a more cautious approach. In Kyllo v. United States, ${ }^{78}$ the Court found that the use of infrared camera technology to scan a home required a warrant. ${ }^{79}$ The Court added the caveat that its decision applied when the technology at issue was not "in general public use." Were the technology in general use, the social norms 
and practices surrounding it would be different, and accordingly people might not reasonably expect privacy in their homes. ${ }^{81}$

In City of Ontario v. Quon, ${ }^{82}$ the Court declined to rule at all on whether text messages sent from workplace phones are protected by the Fourth Amendment. ${ }^{83}$ It expressly warned of the difficulties of addressing a new technology "before its role in society has become clear." ${ }^{\text {" Wh }}$ When a technology is mature and its social role is more defined, the Justices can rely on their own knowledge and experience to determine the scope of the Fourth Amendment. ${ }^{85}$ But here, " $[\mathrm{r}]$ apid changes in the dynamics of communication and information transmission are evident not just in the technology itself but in what society accepts as proper behavior." ${ }^{86}$ Because it was uncertain how the relevant social norms would evolve, the Court declined to weigh in. ${ }^{87}$

The Supreme Court's caution in addressing new technologies not associated with clear social norms is also reflected in its reluctance to take cases involving such technologies. Despite the ongoing proliferation of information and surveillance technologies in the digital era, the Court has decided relatively few Fourth Amendment cases outside of traditional law enforcement contexts. ${ }^{88}$ In recent years, the Court has declined to review cases involving a wide variety of novel technologies, including surveillance

\footnotetext{
81 See Kerr, supra note 24, at 541.

82560 U.S. 747 (2010).

83 See id. at 758-59. The Court did resolve the case on narrower grounds, holding that, even if the Fourth Amendment protected work text messages, the search of Quon's messages were justified by the special needs of his workplace and the non-criminal purpose of the initial review of his messages. Id. at 760-61.

${ }^{84}$ Id. at 759 .

${ }^{85} \mathrm{Id}$.

${ }^{86} \mathrm{Id}$.

${ }^{87} I d$. ("At present, it is uncertain how workplace norms, and the law's treatment of them, will evolve.”).

${ }^{88}$ For an example of this phenomenon in the Fourth Amendment search context, which is especially affected by new surveillance technologies, see Matthew Tokson, The Emerging Principles of Fourth Amendment Privacy, 88 GEO. WASH. L. REV. 1, 59 (2020).
} 
cameras, ${ }^{89}$ web surfing tracking, ${ }^{90}$ email to/from data, ${ }^{91}$ real-time cell phone tracking, ${ }^{92}$ cell tower simulators, ${ }^{93}$ cell tower dumps involving the disclosure of every user proximate to a cell tower, ${ }^{94}$ images uploaded to a photo storage site, ${ }^{95}$ and internet subscriber information. ${ }^{96}$ Even when the Court does resolve cases involving new technologies, it often resolves these cases on narrow grounds, explicitly limiting the impact of its reasoning for future cases. $^{97}$ This has significant downstream effects. Lower courts regularly cite

89 United States v. Houston, 813 F.3d 282, 287-88 (6th Cir. 2016), cert. denied, 137 S. Ct. 567 (2016) (denying certiorari in a case involving a pole camera pointed at defendant's residence); United States v. Wymer 654 Fed. Appx. 735, 743 (6th Cir. 2016), cert. denied. 137 S. Ct. 832 (2017) (same).

${ }^{90}$ United States v. Forrester, 512 F.3d 500, 510 (9th Cir. 2008), cert. denied sub nom., Alba v. United States, 555 U.S. 908 (2008) (denying certiorari in a case where the government obtained a list of IP addresses of websites a suspect had visited); United States v. Ulbricht, 858 F.3d 71, 97 (2d Cir. 2017), cert. denied 138 S. Ct. 2708 (2018) (same).

${ }^{91}$ Forrester, 512 F.3d at 510, cert. denied sub nom., Alba, 555 U.S. at 908 (denying certiorari in a case where the government obtained a list of emails sent to and from a suspect).

92 United States v. Riley, 858 F.3d 1012, 1018 (6th Cir. 2017), cert. denied, 138 S. Ct. 2705 (2018) (denying certiorari in a case involving real-time cell phone location tracking); United States v. Powell, 847 F.3d 760, 770 (6th Cir. 2017), cert. denied, 138 S. Ct. 143 (2017) (same). 93 United States v. Sanchez-Jara, 889 F.3d 418, 421 (7th Cir. 2018), cert. denied, 139 S. Ct. 282 (2018) (denying certiorari in a case involving simulated cell towers capable of capturing nearby individuals' cell phone signals); United States v. Patrick, 842 F.3d 540, 545 (7th Cir. 2016), cert. denied, 138 S. Ct. 2706 (2018) (same).

94 E.g., United States v. Adkinson, 916 F.3d 605, 610 (7th Cir. 2019), cert. denied, 139 S. Ct. 2762 (2019) (denying certiorari in a case involving cell tower dumps).

95 United States v. Morel, 922 F.3d 1, 10 (1 st Cir.), cert. denied, 140 S. Ct. 283 (2019) (denying certiorari in a case involving the government's searching a defendant's images on Imgur.com).

96 E.g., United States v. Wellbeloved-Stone, 777 F. App’x 605, 607 (4th Cir. 2019), cert. denied, 140 S. Ct. 876 (2020) (denying certiorari in a case involving the government's obtaining subscriber information associated with the defendant's IP address).

${ }^{97}$ Carpenter v. United States, 138 S. Ct. 2206, 2220 (2018) (“Our decision today is a narrow one. We do not express a view on matters not before us: real-time [cell-site location information (CSLI)] or ... a download of information on all the devices that connected to a particular cell site during a particular interval ... Nor do we address other business records that might incidentally reveal location information.") (internal parenthetical marks omitted); United States v. Jones, 565 U.S. 400 (2012) (holding that police placement of a GPS device on a car violated the Fourth Amendment on the narrow ground that the physical touching of the car was a quasi-trespass); Mary-Rose Papandrea, Moving Beyond Cameras in the Courtroom: The U.S. Supreme Court, Technology, and the Media, 2012 B.Y.U. L. REV. 1901, 1934-38 (noting the narrowness of the Court's technology-related decisions). 
the Supreme Court's narrowing language as a basis for denying privacy rights in cases involving novel technologies not yet analyzed by the Court. ${ }^{98}$

\section{LAW AND THE CONSTRUCTION OF SOCIAL NORMS}

As we have seen, courts often decide Fourth Amendment cases by looking to social norms. Courts assessing those norms typically perceive them as settled and unchanging. Taking social norms as received wisdom or as social facts of life is to adopt what we are calling the closure principle, or the idea that social norms can be definitively settled. This Part leverages the legal and sociological literatures on norms to argue that norms rarely permanently stabilize, and undergo frequent contestation and change. Further, norms are not prior to law and law has a critical role to play in nudging and creating new norms that challenge existing surveillance and enforcement practices.

\section{A. Law's Influence on Social Norms}

Social norms are neither immutable nor independent of the societal institutions they frame. ${ }^{99}$ They are constantly being contested and reevaluated. ${ }^{100}$ And even when they do seem to stabilize, norms are susceptible to nudges and, less frequently, shocks. ${ }^{101}$ Law has the capacity to alter social norms through its expressive force and ability to reshape behavior and social values. ${ }^{102}$ For example, laws about marriage influence ideas about gender, sex, and monogamy. ${ }^{103}$ Laws protecting digital civil rights arguably affect people's perceptions of and willingness to engage in online harassment. ${ }^{104}$ And laws about police searches influence our perceptions of

98 E.g., United States v. Kidd, 394 F. Supp. 3d 357, 362 (S.D.N.Y. 2019); United States v. Kelly, 385 F. Supp. 3d 721, 726 (E.D. Wis. 2019).

99 Emile Durkheim, Rules of Sociological Method 52 (Steven Lukes ed. 1982) (defining "social facts" as the external coercive norms that both reflect and are changed by society).

100 Id. at 50-59.

101 See Richard H. Thaler \& Cass R. Sunstein, Nudge: Improving DeCisions About HeALth, WeALTH, AND Happiness 67-68 (2008).

102 Cass R. Sunstein, On the Expressive Function of Law, 144 U. PA. L. REV. 2021, 2022 (1996).

103 Elizabeth S. Scott, Social Norms and the Legal Regulation of Marriage, 86 VA. L. REV. 1901 (2000).

104 See Danielle Keats Citron, Cyber Civil Rights, 89 B.U. L. REV. 61, 90-91 (2009) (arguing that a civil rights agenda for online harassment would "inhibit abusive behavior" through 
privacy and uses of technology. ${ }^{105}$ In this section, we push back against judicial adoption of the closure principle by first describing the generative relationship between law and social norms and then showing how law plays a role in directly and indirectly defining technology's place in society.

Legal scholars used to assume that laws and norms were separate systems of social control. ${ }^{106}$ For example, Robert Ellickson's groundbreaking study showing how residents of Shasta County, California resolved their disputes amongst themselves using extra-legal norms painted a picture of social norms as largely independent of law. ${ }^{107}$ Others suggested that law and norms played related, yet distinct roles in governing social and commercial transactions: "warm" social norms govern ongoing commercial relationships while "cold" law comes in as a last resort. ${ }^{108}$

Scholars now understand that law plays a far more influential role. The modern consensus is that, more than just parallel systems of social control, norms and law influence each other. In particular, as Cass Sunstein argued, law is an instrument of norm production and guidance, influencing people's behavior by indirectly signaling what society thinks is good or bad, moral or evil, appropriate or not. ${ }^{109}$ Law has an "expressive function," 110 not just a coercive one, that creates "cultural consequences." burning, for example, are primarily expressive in character: If they ever were to pass, these laws would have insignificant coercive effects because flag

norm generation); Danielle K. Citron, Law's Expressive Value in Combating Cyber Gender Harassment, 108 MiCH. L. REV. 373 (2009) (exploring the argument in more detail).

105 See infra Part III.

106 See, e.g., Robert D. Cooter, Decentralized Law for a Complex Economy: The Structural Approach to Adjudicating the New Law Merchant, 144 U. PA. L. REV. 1643, 1647 (1996) (arguing that law should generally reflect social norms); Lisa Bernstein, Merchant Law in a Merchant Court: Rethinking the Code's Search for Immanent Business Norms, 144 U. PA. L. REV. 1765, 1766-71 (1996) (distinguishing between relationship-preserving norms and "endgame" law).

107 Robert C. Ellickson, Order Without Law: How Neighbors Settle Disputes (1991).

108 See Richard H. Pildes, The Destruction of Social Capital Through Law, 144 U. PA. L. REV. 2055, 2056 (1996) (citing INGA MARKOVITS, IMPERFECT JUSTICE: AN EAST-WEST GERMAN DiARY 44, 55 (1995)).

109 Sunstein, supra note 102, at 2022-24.

${ }^{110} I d$. at 2024. See also Deborah Hellman, The Expressive Dimension of Equal Protection, 85 MINN. L. REV. 1, 39-40 (2000) (arguing for an interpretation of Equal Protection focusing on the expressive effects of discrimination, not the intent of the state actor).

111 Richard Pildes, The Unintended Cultural Consequences of Public Policy, 89 MiCH. L. REV. 936, 938 (1991). 
burning is exceedingly rare. Instead, supporters see flag burning laws as "statement[s] about the venality of the act of flag burning, perhaps in order to affect social norms." 112 Laws with more tangible direct effects, including environmental restrictions like the federal Endangered Species Act and local composting rules, are also expressive: they are "symbol[s] of a certain conception of the relationship between human beings and their environments" and hope to engender eco-friendly habitual human behavior. $^{113}$

Beyond their expressive function, law can affect norms in a variety of ways. Dan Kahan has argued that "gentle nudges" can incrementally change existing social norms by encouraging individuals to "revise upward their judgment of the degree of condemnation warranted by the conduct in question." 114 A law that tries to create or entrench new norms through severe, disproportionate punishments-what Kahan calls a "hard shove"however, could backfire. Law's role in changing attitudes about smoking is a notable example of the efficacy of gentle nudges. Faced with a population for which smoking was not only ordinary but also celebrated on television, Congress moved slowly, first requiring warning labels and then banning television advertisements. ${ }^{115}$ These initial steps reflected a "segmentation strategy" that still respected individual autonomy but, at the same time, burdened that choice to smoke with symbolic condemnation. ${ }^{116}$ Over time, a steadily increasing number of restrictions on smoking-where people could smoke, how much they had to pay, and who could buy them-tapped into growing "resentment" from nonsmokers about the dangers of second-hand smoke that allowed the law to catalyze additional social sanctions, thereby helping norms around smoking to resettle at point far removed from a once pro-smoking culture. ${ }^{117} \mathrm{Had}$ we assumed that norms around smoking had hardened in the 1950s, today's television shows might still be sponsored by Philip Morris.

112 Sunstein, supra note 102, at 2023.

113 Id. at 2024.

114 Kahan, supra note 15, at 611.

115 Id. at 626.

116 Put another way, choosing to smoke while knowing its dangers is a choice, but with attendant moral implications. Id. at 627.

${ }^{117} I d$. at 627-28. Gently nudging existing social norms through incremental steps is most likely to succeed at changing norms if the incremental rules are enforced consistently and conspicuously. $I d$. at 611 . 
Law, especially in the form of a bright-line rule, also clarifies appropriate behavior when norms are vague. Elizabeth Scott gives the example of elementary and secondary school truancy laws. ${ }^{118}$ Scott notes that parents had always been subject to a vague norm about educating their children, but up until the early twentieth century, it had never been clear that good parenting necessarily meant keeping children in school throughout their childhood. ${ }^{119}$ Attendance laws changed that. After their passage, parents had a specific mandate around which they could structure their responsibilities for educating their children. Indeed, compulsory attendance laws were justified and sold to parents as ways to help them educate their children, create good citizens, and become good parents themselves. ${ }^{120}$ This education norm, clarified by a specific legal requirement, was eventually internalized as a hallmark of good parenting. ${ }^{121}$

Alex Geisinger has argued that law can change our beliefs about both the morality and practical utility of activities by "providing information or by influencing the inferential reasoning process." 122 Laws that mandate that drivers wear seatbelts were effective at changing social norms because they came alongside publicized information about the dangers of riding without "buckling up." Likewise, research has shown that public health interventions that focused on increasing awareness of the harms of smoking had a significant effect on smoking cessation rates. ${ }^{123}$

On a more structural level, law is one of several social institutions that set discourses of power that influence our understanding, assumptions, and debates about social life. Discourses, as Michel Foucault explained, are the background knowledge, ideologies, assumptions, and modes of thought behind what we mean when we think and talk about a concept, from privacy to sexuality. ${ }^{124}$ For example, in describing social understandings of

\footnotetext{
118 Scott, supra note 103, at 1927.

${ }^{119} \mathrm{Id}$.

${ }^{120} \mathrm{Id}$.

${ }^{121} \mathrm{Id}$. at 1926-27.

122 See Alex Geisinger, A Belief Change Theory of Expressive Law, 88 IowA L. REV. 35, 70 (2002).

123 See, e.g., Bas van den Putte, Marco C. Yzer \& Suzanne Brunsting, Social Influences on Smoking Cessation: A Comparison of the Effect of Six Social Influence Variables, 41 Preventative Med. 186 (2005); W.H. Bruvold, A Meta-Analysis of Adolescent Smoking Prevention Programs, 83 AM. J. Pub. Health 872 (1993).

${ }^{124}$ Michel Foucault, The Archaeology of Knowledge (1972); Michael Foucault, Order of Discourse, in UnTYING THE TEXT: A POST-STRUCTURALIST READER 48-78 (Robert Young ed., 1981).
} 
homosexuality, Foucault argued that, at a given time in history, our conception of what homosexuality means is influenced by the ideas, arguments, and language from institutions like religion (which only recently started to see same-sex relationships and same-sex sodomy as anathematic to religious dogma) and science (which evolved from defining homosexuality as a disease and then, by the latter part of the Twentieth Century, the opposite). ${ }^{125}$ Law played a central role in defining queer people as "others," as well. "As defined by the ancient civil or canonical codes, sodomy was a category of forbidden acts ...."126 Modern criminal approaches to sodomy, vagrancy laws, and unevenly enforced laws against public solicitation perpetuated bourgeois discourses that marginalized gay people as "abnormal" and kept them out of power. ${ }^{127}$ The feminist scholars Reva Siegal, Judith Butler, Kathleen Jones, and Catharine MacKinnon have made similar arguments about the way law-alongside medicine, religion, and politics - have constructed gender norms to marginalize women. ${ }^{128}$ Adopting the closure principle, then, can entrench the discourses of power embedded in society by other social groups. ${ }^{129}$

Although all of the functional mechanisms of law's expressive value seem to suggest that new laws generate new norms, repealing a law and deregulating some aspect of social life can just as effectively indicate old norms' obsolescence and generate new social norms in their place. Since the Supreme Court held criminal sodomy laws unconstitutional in Lawrence $v$. Texas, ${ }^{130}$ for example, attitudes toward and support for queer equality have changed, with social norms generally favoring equality and more acceptance. ${ }^{131}$ Prior to Lawrence, the persistence of anti-sodomy laws

125 Michel Foucault, The History of Sexuality, Volume 1, An Introduction (Robert Hurley trans., 1980).

126 Id. at 90 .

${ }^{127}$ Id. at 95. See also Paul H. Gebhard et al., SEX OfFENDERS: AN ANALYSIS OF TYPES 324

(1965) ("[T] he law against adult homosexual activity is designed not for the protection of person or property but for the enforcement of our cultural taboo against homosexuality.'). 128 See Reva Siegel, Reasoning from the Body: A Historical Perspective on Abortion Regulation and Questions of Equal Protection, 44 STAN. L. REV. 261 (1992); JUDITH BUTLER, GENDER Trouble: Feminism AND the SubVERsion OF IDENTITY (1990); CATHARINe A. MacKinnon, TOWARD a FEminist TheOry OF THE STATE (1989); Kathleen B. Jones, On Authority: Or, Why Women Are Not Entitled to Speak, 29 NomOs 152 (1987).

129 See infra Part III.A.

130539 U.S. 558 (2003).

131 PeW ReSEArch CTR., The Partisan Divide on Political Issues Grows Even Wider: 5. 
reinforced discriminatory social norms even in the absence of enforcement. ${ }^{132}$ "E] contempt for certain classes of citizens" 133 by establishing gay people as presumptive criminals_or "scum," to use the philosopher Richard Mohr's term $^{134}$ —on the basis of their status and sexual identity alone. Janet Halley similarly argued that maintaining sodomy laws, and the associated debates about them, contribute to stigma and force people into the closet, stating that "[t]he role of law in constituting persons by providing a forum for their conflicts over who they shall be understood to be is deeply material, ... it involves ... the more subtle dynamics of representation." ${ }^{135}$ Christopher Leslie went even further, demonstrating how sodomy laws did violence to queer psychological well-being, encouraged anti-queer violence, and enabled police harassment. ${ }^{136}$ These attacks were rationalized by sodomy law's expressive function: if the law said gay people were presumptive criminals, then they did not deserve constitutional rights. ${ }^{137}$ Throughout, law played a central role in shaping social norms around homosexuality, first reinforcing hostile norms and then helping to generate more positive ones.

Homosexuality, Gender, and Religion (Oct. 5, 2017),

https://www.pewresearch.org/politics/2017/10/05/5-homosexuality-gender-and-religion; PEW RESEARCH CTR., Support for Same-Sex Marriage Grows, Even Among Groups that Had Been Skeptical (June 26, 2017), https:/ /www.pewresearch.org/politics/2017/06/26/support-forsame-sex-marriage-grows-even-among-groups-that-had-been-skeptical; PEW RESEARCH CTR., Support Steady for Same-Sex Marriage and Acceptance of Homosexuality (May 12, 2016), https://www.pewresearch.org/fact-tank/2016/05/12/support-steady-for-same-sexmarriage-and-acceptance-of-homosexuality. Correlation does not necessarily imply causation, of course.

132 See, e.g., Hunter, supra note 16, at 1536; Eskridge, Jr., supra note 16, at 1069. See also Mazzone, supra note 16, at 1041 (giving sodomy laws as an exemplar of law's expressive value).

133 Dan M. Kahan, The Secret Ambition of Deterrence, 113 HARV. L. REV. 413, 421 (1999).

134 RiCHARD D. MOHR, GAYs/JustiCE: A STUdy OF ETHICS, SOCIETY, AND LAW 60 (1988).

135 Halley, supra note 16 , at 1729.

136 Leslie, supra note 16, at 103.

137 Justice Lewis Powell, who provided the swing vote to uphold anti-gay sodomy laws in Bowers $v$. Hardwick, 478 U.S. 186 (1986), rationalized his position by saying that the laws could not do much harm because they were rarely enforced. His vote was a "close call" and "probably ... a mistake", he said, but he considered it "of little or no importance" because no one had been convicted or sent to jail. Aaron Epstein, Ex-Justice Admits 'Mistake' in Gay Ruling, Austin-American Stateman, Oct. 26, 1990, at A2. In fact, the persistence of antisodomy laws - and their attendant effects on social norms - had real negative effects for queer people. 


\section{B. Law and the Construction of Technology}

Law also creates and modifies norms around uses of new technologies. Smartphones, GPS, email, cloud storage, and almost any other digital technology at issue in Fourth Amendment cases are creations of social institutions rather than just creatures of code. ${ }^{138}$ The ways we use them and our expectations of privacy that attend those uses are no more "received wisdom" than other evolving social norms. Therefore, accepting norms around technology as stable before the law has its say is to deny law a place in what Science and Technology Studies (STS) call the "social construction of technology," or SCOT, a process in which different social institutions fight to define technology's place in society. ${ }^{139}$

STS scholars argue that technologies are not just discovered or built out of raw materials or lines of code. Rather, technologies are constructed: they are the products of human relations, understood by people, and used in daily life in ways sometimes unintended by their designers. Technologies are social artifacts because they are used, changed, and repurposed by people and institutions long after they are put on the market. ${ }^{140}$ New technologies undergo a period of "interpretive flexibility" during which users have different understandings of how things work and the purpose they serve, vying to establish different social norms in the process. ${ }^{141}$ For example, when rural farmers, who initially resisted the automobile as a threat to their way of life, started using the Model $\mathrm{T}$ as a stationary power source on their farms,

138 Bruno Latour, The Pasteurization of France (Alan Sheridan \& John Law trans., 1993); Michel Callon, Some Elements of a Sociology of Translation: Domestication of the Scallops and the Fishermen of St. Brieuc Bay, in POwer, Action AND Belief: A New Sociology of KNOWLEDGE? 196-229 (John Law ed., 1987) (1984); Michel Callon, The Sociology of an ActorNetwork: The Case of the Electric Vehicle, in MAPPING THE DYNAMICS OF SCIENCE AND TeChnology 19-34 (Michel Callon et al. eds., 1986); Bruno LATOUR, SCIENCE IN ACTION: HOW TO FOLLOW SCIENTISTS AND ENGINEERS THROUGH SOCIETY (1988).

139 The Social Construction of TeChnological Systems: NeW Directions in the SOCIOlOGY AND History OF TECHNOLOGY (Wiebe E. Bijker et al. eds., 2012).

140 Trevor J. Pinch \& Wiebe E. Bijker, The Social Construction of Facts and Artefacts: Or How the Sociology of Science and the Sociology of Technology Might Benefit Each Other, in Wiebe E. Bijker, Thomas P. Hughes, and Trevor Pinch eds., THE SOCIAL CONSTRUCTION OF TeChnological Systems: NeW Directions in the SOCIOlOgy AND History of TECHNOLOGY 17-50 (1987).

141 See Cynthia Cockburn \& Susan Ormrod, Gender and Technology in the MAKING 1-15 (1993) 
they became "agents of technological change." ${ }^{142}$ Farmers used cars to power lights and machinery and to transport goods rather than people. Designers and manufacturers who resisted using the car as a simple power source tried to counteract this: they elevated the car's rear wheels to make it difficult to double as a stable power source and built and marketed separate gasoline engines that could provide power when needed. ${ }^{143}$ As a result, farmers created norms that influenced the next iteration of the car and spurred the creation of new products.

The telephone, surprisingly enough, was not intended to be a tool of social communication when it was first built. The enterprises that built the first phones designed them purely for businesses or government agencies to transmit information over long distances. As Michele Martin describes, rural women had a different idea. They used telephones to create the social contact they lacked under a patriarchal system that kept women in the home. Their norms forced changes in design of both the phones themselves and the wires that made communication possible. ${ }^{144}$ Bijker has shown that when the highwheeled bicycle was introduced, older men tried to establish a norm of nonuse, designating it as unsafe. This which paved the way for the development of a new, safer, smaller-wheeled bicycle several years later. ${ }^{145} \mathrm{In}$ all of these contexts, consumers identified new uses for products that designers never intended, ultimately leading to changes in design. ${ }^{146}$

Law is one of the social institutions involved in the social construction of technology. Law undoubtedly affects technology design. Intellectual property, tort, and products liability law, among other areas, directly affect how technologies are made. For instance, patent and copyright law encourages innovators to "invent around" or "create around" others' designs and hold creators liable for infringement when they get too close to an existing product. ${ }^{147}$ Trade secrecy law influences how competing products are

\footnotetext{
142 Ronald Kline \& Trevor Pinch, Users as Agents of Technological Change: The Social Construction of the Automobile in the Rural United States, 37 TECH. \& CULTURE 763, 764 (1996).

${ }^{143}$ Id. at $775-84$.

144 Michelle Martin, Hello, Central?: Gender Technology and Culture in the FORMATION OF TELEPHONE SYSTEMS 5-9 (1991).

145 Wiebe E. Bijker, OF Bicycles, Bakelites, And Bulbs: Toward A Theory of SOCIOTECHNICAL CHANGE (1995).

146 See, e.g., Susan Douglas, InVEnting American Broadcasting, 1899-1922 (1987)

(users developed new ways to deploy radio technology).

147 See Joseph P. Fishman, Creating Around Copyright, 128 HARV. L. REV. 1333, 1351-358
} 
designed: reverse engineering is permissible, but not if it is based on unlawfully obtained information. ${ }^{148}$ Tort law has generated a series of behavioral standards that define how companies design, manufacture, and market products. ${ }^{149}$

We already see law directly influencing the designs and norms of information technologies, as well. When the information industry introduced end-to-end encryption and eliminated so-called "back doors" that governments could use to access information on smartphones and other platforms, the U.S. Department of Justice pushed back, citing national security concerns. ${ }^{150}$ Law enforcement attempted to use the All Writs Act to force Apple to design a "back door" into the iPhone owned by the domestic terrorist who killed 14 people at a San Bernardino community center in 2015. ${ }^{151}$ The General Data Protection Regulation, the European Union's comprehensive data privacy law, and the California Consumer Privacy Act, a structurally similar privacy law that took effect on January 1, 2020, both guarantee individuals the right to access information about them stored by data collectors. ${ }^{152}$ Those provisions have required companies to redesign their databases and user interfaces to allow data requests, searches, and transmission. ${ }^{153}$ In addition, as nations tried to use technology-enhanced

(2015) (discussing the principles of "inventing" or "creating" around in patent and copyright law).

148 See, e.g., Rochelle Cooper Dreyfuss, Do You Want to Know a Trade Secret? How Article 2B Will Make Licensing Trade Secrets Easier (But Innovation More Difficult), 87 CAL. L. REV. 191, 207 (1999) ("misappropriation does not include reverse engineering").

149 See, e.g., Bly v. Otis Elevator Co., 713 F.2d 1040, 1046 (4th Cir. 1983); Lewis v. Timco, Inc., 716 F.2d 1425, 1429 (5th Cir. 1983); Micallef v. Miehle Co., 348 N.E.2d 571, 577 (N.Y. 1975); Barker v. Lull Eng'g, 573 P.2d 443, 457 (Cal. 1978); John W. Wade, On the Effect in Product Liability of Knowledge Unavailable Prior to Marketing, 58 N.Y.U. L. REV. 734, 739 (1983). 150 Encryption: The Threat, Applications and Potential Solutions (visited July 24, 2020), http://www.epic.org/crypto/ban/fbi_dox/mandatory.gif (showing scanned copy of the briefing document provided to the National Security Council).

151 Gov't's Ex Parte Application for Order Compelling Apple Inc. to Assist Agents in Search; Memorandum of Points and Authorities, In re Matter of the Search of an Apple iPhone Seized During the Execution of a Search Warrant on a Black Lexus IS300, California License Plate 35KGD203 (C.D. Cal. Feb. 19, 2016) (No. 16-10), at 1.

152 See Regulation 2016/679, of the European Parliament and of the Council of 27 April 2016 on the Protection of Natural Persons with Regard to the Processing of Personal Data and on the Free Movement of Such Data, and Repealing Directive 95/46/EC, May 4, 2016, 2016 O.J. (L 119); Cal. Civ. Code \1798.100 (West 2018) [hereinafter “GDPR”].

153 See Niall McCreanor, How to Maintain GDPR-Compliant Databases, IT GOVERNANCE (Feb. 
contact tracing to manage outbreaks during the 2020 Covid-19 pandemic, privacy law in Europe and privacy regulators in the United States facilitated the creation of decentralized tracing apps that preserved some level of privacy while allowing health experts to track Covid hotspots. ${ }^{154}$

Privacy law does this as well by influencing norms around sharing and design. Danielle Citron has argued that creating special legal protections for sexual privacy can encourage people to value their privacy when downloading menstruation apps or disclosing HIV status on a dating app. ${ }^{155}$ One of us has written that privacy law could help generate and protect norms of trust among individuals. ${ }^{156}$ And Margot Kaminski has suggested that one of the goals of compliance requirements in the GDPR, including privacy impact assessments and other internal structures, is to nudge behavioral and design norms inside the information industry. ${ }^{157}$ These are just a few examples of how law is part of the process by which new technologies are interpreted, constructed, and understood in society.

\section{CHALlEnging NORM RELIANCE AND JUDICIAL NONINTERVENTION IN FOURTH AMENDMENT LAW}

Where norms seem stable and settled, they often define our Fourth Amendment rights; where norms appear to be in flux, they are left to evolve on their own, free of judicial intervention. That is our descriptive claim. In this Part, we make our normative claim: Both of these practices substantially

16, 2018), https://www.itgovernance.eu/blog/en/how-to-maintain-gdpr-compliantdatabases.

154 See Stephanie Rossello \& Pierre Dewitte, Anonymization by Decentralization? The Case of COVID-19 Contact Tracing Apps, European LAw Blog (May 25, 2020), https:// europeanlawblog.eu/2020/05/25/anonymization-by-decentralization-the-case-ofcovid-19-contact-tracing-apps.

155 Danielle Keats Citron, A New Compact for Intimate Information, 62 WM. \& MARY L. REV. (forthcoming 2020); Danielle Keats Citron, Sexual Privacy, 128 YALE L.J. 1870, 1889-90 (2019) [hereinafter Citron, Sexual Privacy].

156 ARI EZRA WALDMAN, PRIVACy As TRUST: INFORMATION PRIVACY FOR AN Information AgE (2018); Ari Ezra Waldman, Safe Social Spaces, 96 WASH. U. L. REV. 1537 (2018). See also Neil Richards \& Woodrow Hartzog, Taking Trust Seriously in Privacy Law, 19 Stan. TECH. L. REV. 431 (2016); Neil Richards \& Woodrow Hartzog, A Duty of Loyalty for Privacy Law (forthcoming 2021) (manuscript on file with authors).

157 Margot E. Kaminski, Binary Governance: Lessons from the GDPR's Approach to Algorithmic Accountability, 92 S. CAL. L. REV. 1529, 1584 (2019). 
weaken the ability of the Fourth Amendment to protect privacy, security, and equality in the information age.

As discussed above, law not only draws on social norms but also shapes them, in an ongoing exchange between social institutions and individuals. Courts deciding Fourth Amendment cases have often failed to appreciate the expressive function of law and its role in driving norms. Courts regularly take norms to be settled, even in areas where they are contested or directly influenced by legal standards.

This failure of understanding leads to concrete judicial errors in the Fourth Amendment context. First, courts may embed outmoded norms in Fourth Amendment law, even as many of those norms discriminate on the basis of race, gender, or class. Second, courts often refrain from addressing government surveillance when the norms surrounding a new technology are unsettled. This practice allows the government to surveil citizens without regulation for years or decades. Moreover, it cedes power over norm development to companies that design new technologies based on an extractive data-for-profit business model, thus skewing social norms toward disclosure and away from privacy. Finally, both the closure and nonintervention principles described above facilitate "surveillance creep," where existing data-gathering structures are used for new types of surveillance.

Relying on the sociolegal and STS literatures described above, we challenge the principles of closure and nonintervention that drive these judicial errors. The following sections detail how courts have embedded discriminatory norms, ceded power over norm development to dataextractive businesses, and failed to anticipate the gradual accretion of government surveillance infrastructure.

\section{A. The Problem of Discriminatory Norms}

Social norms are rarely fully settled and are subject to contestation and change. Norms surrounding race, gender, class, and related issues are particularly likely to be challenged and to shift over time. Courts applying "settled" social norms are thus at risk of reifying outmoded, discriminatory concepts. This section explores this process, detailing how courts' seemingly neutral applications of existing norms have embedded discriminatory ideas in Fourth Amendment law. 


\section{Racially Discriminatory Norms}

Courts basing Fourth Amendment law on prevailing social customs may entrench discriminatory norms that disadvantage citizens of color. In the Supreme Court's norm-based Fourth Amendment cases, the Court often looks to social practices as an objective basis for rules governing policecitizen interactions. Its assessments of prevailing social customs may be empirically accurate-most people may act as the Court predicts. But the very act of enshrining social norms in constitutional law can reinforce discriminatory norms and make it more difficult for citizens to challenge them.

In Illinois $v$. Wardlow, ${ }^{158}$ the Court concluded that the police could stopand-frisk a Black suspect who ran away after seeing several police cars. ${ }^{159}$ The police made a "commonsense judgement $[$... about human behavior," the Court said, and found that running away from police was suspicious and indicative of wrongdoing. ${ }^{160}$ Several Justices in dissent pointed out that Black people have legitimate fears of police brutality and other harms stemming from police interaction that may cause them to flee at the sight of officers even without having done anything wrong. ${ }^{161}$ But the majority concluded that Wardlow's fleeing behavior was sufficiently unusual as to arouse suspicion, and thus the officers' actions were justified. ${ }^{162}$

Empirical studies cast doubt on the idea that people fleeing the police are regularly engaged in wrongdoing. ${ }^{163}$ But the problem here is not the Court's empirical conclusion about how usual it is for a person to run away

\footnotetext{
158528 U.S. 119 (2000).

${ }^{159} I d$. at 121.

$160 \mathrm{Id}$. at 125.

${ }^{161} \mathrm{Id}$. at 132-33 (Stevens, J., concurring in part and dissenting in part). For further discussion of $W$ ardlow and the reasons Black citizens may have for fleeing the police, see Tovah Renee Calderon, Race-Based Policing from Terry to Wardlow: Steps Down the Totalitarian Path, 44 How. L.J. 73, 101-02 (2000).

162 Wardlow, 528 U.S. at 124-25. The Court also reasoned that police stops were relatively "minimal" intrusions that could be justified by a relatively low level of individualized suspicion. Id. at 126 .

163 Tracey L. Meares \& Bernard E. Harcourt, Foreword: Transparent Adjudication and Social Science Research in Constitutional Criminal Procedure, 90 J CRIM. L. \& CRIMINOLOGY 733, 790 (2000) (reporting that suspects who fled upon seeing the police were arrested in only 1 out of every 15.8 encounters, and suspects who fled the police in high-crime areas, like Wardlow, were arrested in only 1 out of every 45 encounters).
} 
after seeing the police. It is the Court's failure to question prevailing social practices of police-citizen interaction, particularly with respect to persons of color, before embedding them in constitutional law. Running away upon seeing a police officer is likely rare overall in part because of substantial racial disparities in police treatment of civilians. ${ }^{164}$ White people have less reason to fear police brutality or degradation, and thus less reason to run away. ${ }^{165}$ Black people may decline to run away in most cases not because they are unafraid of the police but because they fear even more what the police will do to them if they flee. ${ }^{166}$ Declining to run may also reflect parental advice to children of color that discourages running in the view of a police officer and counsels maximal compliance in order to minimize the risk of being harmed by the police. ${ }^{167}$ The Court, in other words, bases Fourth Amendment law on a prevailing social practice without asking why that practice exists. Nor does it ask whether the law should work to change that practice. In doing so, it embeds into constitutional law a practice with racially disparate effects.

In Drayton $v$. United States, ${ }^{168}$ several police officers boarded a Greyhound bus, guarding the exits, while one officer asked to search Drayton's bag and pat-down his clothes. ${ }^{169}$ The Court's conclusion that this was not a seizure rested on the idea that bus passengers would generally feel free to decline police requests to search their bags and would leave the bus if they wanted to terminate the encounter. ${ }^{170}$ The Court noted that most people complied with such requests, presumably out of a desire to promote law enforcement and enhance safety. ${ }^{171}$ Setting aside whether the Court was correct about the prevailing social practice of complying with police search requests, the Court failed to examine why this social norm exists.

Like other members of traditionally marginalized groups, Black people may be especially reluctant to challenge police authority or decline police

\footnotetext{
164 See, e.g., Diana R. Donahoe, Not-So-Great Expectations: Implicit Racial Bias in the Supreme Court's Consent to Search Doctrine, 55 AM. CRIM. L. REV. 619, 637 (2018).

165 Malcolm D. Holmes \& Brad Smith, Race and Police Brutality: Roots of an URBAN DilEMMA 28-35 (2008).

166 See I. Bennett Capers, Criminal Procedure and the Good Citizen, 118 CoLuM. L. REV. 653, 696-98 (2018).

${ }^{167}$ Utah v. Strieff, 136 S. Ct. 2056, 2070 (2016) (Sotomayor, J., dissenting).

168536 U.S. 194 (2002).

${ }^{169} \mathrm{Id}$. at $197-98$.

${ }^{170}$ Id. at 203-4, 206.

${ }^{171} \mathrm{Id}$. at 205.
} 
requests in a situation like the one in Drayton, where Drayton, a Black man, was surrounded by officers in a confined space. ${ }^{172}$ Black children are often counseled by parents and other trusted figures to defer to the police as much as possible, not to move or flee, and to comply with every request. ${ }^{173}$ Thus a standard like Drayton's, which depends on a person refusing to talk to police officers or brushing past them to leave a bus, may be harmful to people of color who cannot assert their rights to noncompliance with police requests without risking serious harm or trauma. ${ }^{174}$ Moreover, psychological studies of consent in law enforcement contexts suggest that the general norm of compliance with police search requests is motivated by intimidation rather than the voluntary choices of citizens. ${ }^{175}$

Even if a court ultimately concludes that the coercive pressure of police bus interdiction is justified by the benefits of searching passengers' bags, ${ }^{176}$ it cannot do so without addressing the disparate racial and ethnic impacts of such an approach. ${ }^{177}$ Yet the Court never grapples with these normative questions, instead choosing to identify a prevailing social practice and adopt it as settled.

\section{Gender-Discriminatory Norms}

Fourth Amendment standards that depend on individuals refusing to comply with police officers likewise disadvantage women relative to men. Survey data suggests that women feel less free to leave police-citizen encounters and may feel the coercive pressure of such encounters more than others. ${ }^{178}$ Linguistic patterns correlated with gender may also result in women, particularly women of color, being less direct with authority figures in ways that may disadvantage them under facially neutral standards of

\footnotetext{
172 See, e.g., Carbado, supra note Error! Bookmark not defined., at 1013-14.

173 See Donahoe, supra note 164, at 642-43.

174 Carbado, supra note Error! Bookmark not defined., at 1018-20.

175 See, e.g., Roseanna Summers \& Vanessa K. Bohns, The Voluntariness of Voluntary Consent: Consent Searches and the Psychology of Compliance, 128 YALE L.J. 1962 (2019).

${ }^{176} \mathrm{It}$ is notable that Drayton was argued only 6 months after the September 11, 2001 attacks, which may have influenced the Court's policy intuitions. It is impossible to know for certain because the Court does not address these issues, instead basing its decisions in norms and practices.

177 See Carbado, supra note Error! Bookmark not defined., at 966-67.

178 David K. Kessler, Free to Leave? An Empirical Look at the Fourth Amendment's Seizure Standard, 99 J. CRIM. L. \& CRIMINOLOGY 51, 75-76 (2009).
} 
normal police-citizen interaction. ${ }^{179}$

Moreover, the jurisprudence of consent searches of homes may reinforce existing norms of domestic privacy at the expense of deterring domestic abuse. The multiple opinions in Georgia v. Randolph parallel an ongoing feminist debate about privacy and domestic abuse without actually addressing it. ${ }^{180}$ Some theorists have argued against the concept of domestic privacy, contending that it provides a cover for physical and psychological abuse. ${ }^{181}$ Others have argued that once the law takes a full account of the privacy and bodily integrity interests of women, the law's general concern for domestic privacy need not shield abusers or prevent government officials from scrutinizing the home in appropriate circumstances. ${ }^{182}$ The Supreme Court largely elided this debate by focusing on social norms and concluding that prevailing norms discourage entering a dwelling when a tenant of that dwelling is present and objects to one's entry. ${ }^{183}$ The Justices were aware of the domestic abuse issue at the time of their decision. ${ }^{184}$ But in setting a general standard, the Court concluded that it should follow its typical practice of giving "great significance ... to widely shared social expectations" and "social custom" in Fourth Amendment consent cases. ${ }^{185}$

Adopting these social norms, however well intentioned, enshrines them in constitutional law without fully addressing their gendered burdens and

179 See Jesse-Justin Cuevas \& Tonja Jacobi, The Hidden Psychology of Constitutional Criminal Procedure, 37 CARDOZO L. REV. 2161, 2170-74 (2016).

180 See Suzanne A. Kim, Reconstructing Family Privacy, 57 Hastings L. J. 557, 575-82 (2006).

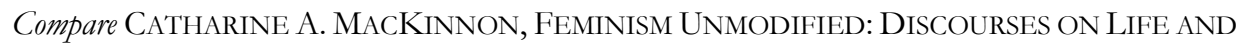
THE LAW 93, 101-02 (1987) and Reva B. Siegel, 'The Rule of Love:' Wife Beating as Prerogative and Privacy, 105 YALE L.J. 2117 (1996), with Citron, Sexual Privacy, supra note 155, at 1876-77; ANITA L. ALLEN, UNEASY ACCESS (1988).

181 See literature cited supra note 180. See also, e.g., State v. Rhodes, 61 N.C. 453, 457 (1868) (establishing a principle of legal nonintervention into marital privacy in a case where a husband struck his wife with a rod).

182 See supra note 180.

183 Randolph, 547 U.S. at 111-12.

184 See id. at 139 (Roberts, J., dissenting). The majority made clear that the police could enter a home over the objection of a co-tenant in order to protect a resident from imminent domestic violence. $I d$. at 118 . In a subsequent case, police officers did enter a home over the objection of a present tenant when they suspected domestic abuse, arrested the abuser, and then obtained consent from the victim to search the house. See Fernandez v. California, 571 U.S. 292, 295-96 (2014). In less clear-cut cases, the ability of officers to intervene in domestic disputes may be limited.

185 Randolph, 547 U.S. at 120. 
implications for victims and survivors of abuse. While the police would be able to enter a house in situations of domestic violence, they may not, under Randolph, be able to do so in cases where violence is not imminent or where the signs of abuse are too ambiguous to allow for entry on the basis of an emergency aid exception. ${ }^{186}$ Likewise, the Randolph rule prohibits police involvement in cases of domestic strife that may act as a precursor to abuse or may implicate child custody. ${ }^{187}$

Randolph's protection of domestic privacy and reluctance to involve police officers in non-abusive domestic disputes may ultimately represent the optimal approach to Fourth Amendment consent law. But the Court's adoption of prevailing social norms cuts short any discussion of the broader implications of its ruling. The Court privileges a norm of social behavior that was developed when gender relations were substantially different than they are today and when women's rights to autonomy and bodily integrity in the domestic context were devalued. ${ }^{188}$ Endorsing norms simply because of their longstanding nature or general acceptance risks embedding discriminatory norms in constitutional law.

\section{Class-Discriminatory Norms}

Courts' adoptions of existing social customs in Fourth Amendment law can also embed norms that systematically disadvantage poorer citizens and privilege those with more money or property. Class-discriminatory norms may also have racially disparate impacts, doubly disadvantaging poor people of color. ${ }^{189}$ The cases adopting these norms uncritically adopt prevailing social practices and entrench stereotypes about wealth and power.

For example, while courts have held that individuals have a Fourth Amendment interest in the yards surrounding their detached homes or the

186 See Jeannie Suk, Is Privacy A Woman?, 97 GEO. L.J. 485, 503 (2009).

187 Indeed, the reason for the initial phone call to the police in Randolph was Scott Randolph's taking his and Janet Randolph's son out of the house to live elsewhere. Randolph, 547 U.S. at 107.

188 The social norm of non-entry over the objection of a tenant likely stretches back decades or centuries, and Randolph points to related legal authorities from the 1960s, 1950s, and before. See Randolph, 547 U.S. at 112-14 (citing Chapman v. United States, 365 U.S. 610, 610 (1961); United States v. Jeffers, 342 U.S. 48, 51 (1951); 2 H. TIFFANY, REAL ProperTy \$S 468, 473, 474, pp. 297, 307-309 (3d ed. 1939 and 2006 Cum. Supp.)).

189 See Eric J. Miller, Property, Persons, and Institutionalized Police Interdiction in Byrd v. United States, 52 LOY. L.A. L. REV. 107, 156 (2018). 
shared areas of small multi-unit homes, ${ }^{190}$ courts typically hold that the Fourth Amendment does not protect the hallways of larger apartment buildings. ${ }^{191}$ This distinction is based on courts' perceptions of the social practices surrounding these areas. A homeowner "exercises greater control" over their yard than apartment dwellers do over their hallways, and, because larger apartments generally receive more visitors, the "more units in the apartment building ... the less reasonable any expectation of privacy." 192 This might be a defensible assessment of social practices, although visitors and delivery people may intrude on a homeowner's yard as well. ${ }^{193}$ But this distinction discriminates between those who own detached houses and those who cannot afford such houses (or simply wish to live in cities) and must share their living spaces with others. The former are likely wealthier, and they are given stronger privacy rights. Courts could just as plausibly find that all dwellings are surrounded by a private area, typically open to a limited set of guests and visitors, and off-limits to warrantless police surveillance. ${ }^{194}$

${ }^{190}$ Collins v. Virginia, 138 S. Ct. 1663, 1670 (2018) (finding a Fourth Amendment violation when police officers entered a home's curtilage to examine a motorcycle parked there); United States v. Fluker, 543 F.2d 709, 716 (9th Cir. 1976) ("In light of the size of the building, then, we find significant the fact that the door to the hallway giving access to the two apartments was locked; the two lower-level tenants thus exercised considerably more control over access to that portion of the building than would be true in a multi-unit complex, and hence could reasonably be said to have a greater reasonable expectation of privacy than would be true of occupants of large apartment buildings.'); Fixel v. Wainwright, 493 F.3d 480, 483-84 (5th Cir. 1974) (holding that a police officer's unwarranted inspection of the shared back yard of a 4-unit apartment house violated the Fourth Amendment).

191 United States v. Concepcion, 942 F.2d 1170, 1172 (7th Cir. 1991) ("The vestibule and other common areas are used by postal carriers, custodians, and peddlers.'); United States v. Eisler, 567 F.2d 814, 816 (8th Cir. 1977) ("The common hallways of Hoff's apartment building were available for the use of residents and their guests, the landlord and his agents, and others having legitimate reasons to be on the premises."). See also United States v. Nohara, 3 F.3d 1239, 1241 (9th Cir. 1993) (finding no reasonable expectation of privacy in an apartment hallway); United States v. Barrios-Moriera, 872 F.2d 12, 14 (2d Cir. 1989) (same), abrogated on other grounds by Horton v. California, 496 U.S. 128 (1990). But see United States v. Carriger, 541 F.2d 545 (6th Cir. 1976) (holding that uninvited police entry into the hallway of a locked apartment building violated the Fourth Amendment on quasi-trespass grounds).

192 United States v. Miravalles, 280 F.3d 1328, 1332 (11th Cir. 2002).

${ }^{193} I d$. at 1332.

194 Indeed the leading case on drug-sniffing dogs points in this direction, although its rationale is difficult to square with the many cases declaring that there is no Fourth Amendment interest in a shared hallway. See United States v. Whitaker, 820 F.3d 849, 853 
Instead, subtle distinctions between the social practices surrounding yards and hallways have driven the case outcomes, despite their disparate impacts. ${ }^{195}$

The Supreme Court's decision in INS v. Delgado ${ }^{196}$ likewise enshrined class-discriminatory norms in the context of immigration enforcement at a garment factory. ${ }^{197}$ The Court concluded that placing armed agents near the factory's exits did not constitute a seizure of the workers inside. ${ }^{198}$ This holding was based on the Court's assessment of the typical social practices of a factory. It found that "when people are at work their freedom to move about has been meaningfully restricted ... by the worker's voluntary obligations to their employers." ${ }^{199}$ While this may be an accurate assessment of the practices of many garment factories, where workers may have little bargaining power and may face excessive work demands and restrictions on personal breaks, it endorses an aggressively anti-worker norm. ${ }^{200}$ The rationale of Delgado is that workers are already obligated to remain inside the factory for the duration of the workday, with little enough personal freedom that the additional restrictions imposed by armed guards do not rise to the level of a Fourth Amendment seizure. ${ }^{201}$ The Court adopts this norm as a lodestar of Fourth Amendment law without questioning its appropriateness or desirability. In doing so, it reinforces disciplinary workplace norms and further undermines workers' power relative to their employers. It also places disproportionate burdens on Latinx workers and may reduce their relative

(7th Cir. 2016).

${ }^{195}$ E.g., Miravalles, 280 F.3d at 1332 ("[T]enants have little control over those areas, which are available for the use of other tenants, friends and visitors of other tenants, the landlord, delivery people, repair workers, sales people, postal carriers and the like."); Concepcion, 942 F.2d at 1172 ("The vestibule and other common areas are used by postal carriers, custodians, and peddlers."); Eisler, 567 F.2d at 816 ("The common hallways of Hoff's apartment building were available for the use of residents and their guests, the landlord and his agents, and others having legitimate reasons to be on the premises.").

196466 U.S. 210 (1984).

${ }^{197} I d$. at 212; Carbado, supra note Error! Bookmark not defined., at 994.

${ }^{198}$ Delgado, 466 U.S. at 212.

${ }^{199}$ Id. at 218.

200 See generally Note, Leslie D. Alexander, Fashioning a New Approach: The Role of International Human Rights Law in Enforcing Rights of Women Garment Workers in Los Angeles, 10 GEO. J. PUB. POL'Y 81, 83-87 (2003) (discussing inhumane conditions and excessive work obligations in garment factories).

${ }^{201}$ Delgado, 466 U.S. at 218. 
status as workers. ${ }^{202}$ The Court's adoption of existing workplace norms can have harmful legal and social implications for workers along several dimensions.

\section{B. The Effects of Nonintervention}

The previous section discussed how courts applying the closure principle have ignored law's role in nudging norms and entrenched in Fourth Amendment law unjust and outdated norms about race, gender, and socioeconomic status. The flip side of closure is nonintervention, where courts remain neutral when they perceive that social norms-particularly those about the uses of surveillance technologies - are still in flux. Judicial insistence on nonintervention where norms are perceived to be unsettledwhat we are calling the nonintervention principle - cedes power to private companies that design new technologies to surveil users rather than protect their privacy. The norms these companies favor are almost always surveillant, powered by the data-extractive business models of informational capitalism. ${ }^{203}$ In addition, nonintervention often permits the government to surveil individuals using new technologies for years or decades without meaningful legal regulation.

\section{Nonintervention and Government Surveillance}

In general, choosing not to act is a choice like any other. It has both consequences and moral valence, and reflects the normative judgment of the decisionmaker. ${ }^{204}$ Judicial nonintervention is also a choice, one that can perpetuate existing injustices. ${ }^{205}$ For example, judicial adherence to a decontextualized form of race and sex neutrality has often undermined

202 Carbado, supra note Error! Bookmark not defined., at 998.

203 COHEN, supra note 23.

204 For a general theoretical discussion of choosing not to choose, see Cass R. Sunstein, Choosing Not to Choose, 64 DuKE L.J. 1, 5-8 (2014).

205 This sentiment is often restated in movements for social justice. For example, Desmond Tutu said, "If you are neutral in situations of injustice, you have chosen the side of the oppressor.” Gary Younge, The Secrets of a Peacemaker, GUARDIAN (May 22, 2009), https://www.theguardian.com/books/2009/may/23/interview-desmond-tutu. To be sure, judicial nonintervention can often promote social justice as effectively as intervention, or even more so. See, e.g., Gerald N. Rosenberg, The Hollow Hope: Can Courts Bring About Social Change? (2nd ed. 2008). 
prospects for justice. ${ }^{206}$ Similarly, when courts stay out of the fray entirely, they may let political majorities entrench their own power at the expense of minority voters. ${ }^{207}$

Proponents of judicial nonintervention in Fourth Amendment law suggest that courts should refrain from regulating the government's use of a new surveillance technology until social norms and practices involving the technology become stable. ${ }^{208}$ Under this laissez, faire regime, norms surrounding emerging technologies should be allowed to develop free of judicial input. ${ }^{209}$ A result of this is that government officials would be allowed to surveil citizens without Fourth Amendment regulation in the long interim period between the development of a new technology and the development of relatively stable social norms. As courts wait for a technology and its associated norms to settle, nonintervention in surveillance cases will typically mean declining to reach the merits of a Fourth Amendment issue, ruling narrowly, or, at the Supreme Court level, simply denying certiorari. ${ }^{210}$

206 Historically, for instance, nonintervention permitted even severe forms of domestic abuse. State v. Rhodes, 61 N.C. 453, 457 (1868).

${ }^{207}$ In Rucho v. Common Cause, the Roberts Court interpreted the political question doctrine to mandate nonintervention in partisan gerrymandering claims. 139 S. Ct. 2484, 2501-02 (2019). Notwithstanding the dissent's step-by-step approach for adjudication, the Court left the work of overturning partisan gerrymanders to the political sphere. See id. at 2508-2525 (Kagan, J., dissenting). But gerrymanders are designed to prevent political checks; they entrench the power of one party (or group) against popular will. Judicial nonintervention in partisan gerrymandering cases, then, leaves minority parties with nowhere to turn, perpetuating the unequal status quo.

208 See, e.g., City of Ontario v. Quon, 560 U.S. 746, 759 (2010) (“The judiciary risks error by elaborating too fully on the Fourth Amendment implications of emerging technology before its role in society has become clear."); Kerr, supra note 24, at 539 (“If a court intervenes too soon, it risks error: it might wrongly assess the need for adjustment because either the technology hasn't evolved to a reasonably stable state or else social practices relating to the use of the technology continue to evolve.”).

209 See supra note 208.

210 Lower courts have several means of avoiding difficult Fourth Amendment issues, including dismissing cases on standing, good faith, qualified immunity, or similar grounds. See, e.g., Sherry F. Colb, Standing Room Only: Why Fourth Amendment Exclusion and Standing Can No Longer Logically Coexist, 28 CARDOZO L. REV. 1663, 1670 (2007) (giving a general theoretical account of modern standing doctrine); Orin S. Kerr, Good Faith, New Law, and the Scope of the Exclusionary Rule, 99 GEO. L.J. 1077, 1084-87 (2011) (surveying the Supreme Court's good faith exception jurisprudence). Lower courts might also rule narrowly, or reach a ruling only in unpublished, nonprecedential decisions, where permitted by local rules. See, e.g., Wash. Gen. R. 14.1 (establishing that unpublished opinions of the Washington Court of 
This approach is problematic because norms rarely definitively settle, ${ }^{211}$ and it may take several years or decades for technologies and norms to stabilize even partially. ${ }^{212}$ The period of "interpretive flexibility" surrounding a new technology is often quite long, as different social groups and actors fight to adapt new technologies to their needs, values, and worldviews. It took the bicycle nearly 100 years to evolve from its first iterations to suit the needs of different social groups. ${ }^{213}$ The telephone is still evolving. ${ }^{214}$ By the time sociotechnical norms stabilize, if they do at all, the government will have had free reign to surveil citizens for a long time.

Proponents of nonintervention have argued that the Supreme Court's erroneous ruling in Olmstead $v$. United States, which upheld warrantless wiretapping, was the result of the Court intervening too fast to rule on a relatively new form of surveillance. ${ }^{215}$ They suggest that the Court could instead have waited another twenty or thirty years as "the use of the telephone in communications continued to change throughout the 1930s, 1940s, and 1950s." ${ }^{216}$ But declining to intervene for several decades would have given the government the ability to massively surveil citizens without judicial supervision throughout that time, rendering the Fourth Amendment toothless. ${ }^{217}$ Moreover, both the telephone and the practice of wiretapping had been around and were well-known for decades prior to Olmstead. ${ }^{218}$ The

Appeals "have no precedential value").

211 See supra Part II.A.

212 See supra text accompanying notes 140-146.

213 See BIJKER, supra note 145.

214 See W.H. Martin, Seventy-Five Years of the Telephone: An Evolution in Technology, 30 BELL SYS. TECH. J. 215 (1951); Lisa Eadicicco, This Is Why the iPhone Upended the Tech Industry, TIME, June 29, 2017, https://time.com/4837176/iphone-10th-anniversary.

215 Kerr, supra note 24, at 539.

${ }^{216} I d$.

217 Six years after Olmstead, Congress passed the Communications Act of 1934 which limited the disclosure of wiretapping evidence in court, but did not effectively deter widespread use and abuse of wiretapping over the following decades. See Communications Act of 1934, ch. 652, \605, 48 Stat. 1064, 1104 (codified as amended at 47 U.S.C. \ 605 (2006)); Matthew Tokson, Automation and the Fourth Amendment, 96 IowA L. REV. 581, 592 (2011) (describing the widespread abuses that occurred the during the decades that followed the passage of the Communications Act of 1934).

218 The telephone was patented in 1876, some fifty-two years prior to Olmstead, U.S. Patent No. 174,465 (issued Mar. 7, 1876), while wiretapping had been used since 1895, thirty-three years prior to Olmstead. Meyer Berger, Tapping the Wires, THE NEW YORKER, June 18, 1938. Wiretapping had been brought to public attention by at least 1916, twelve years before 
Court's error in Olmstead was not the result of technological unfamiliarity or a failure to wait for norms to settle, but rather of excessive formalism and textual literalism. ${ }^{219}$

By failing to intervene when issues of technological surveillance arise, courts would allow government surveillance to go unchecked by the Fourth Amendment for years or decades. Further, by the time sociotechnical norms become relatively stable, the government may have already moved on to a new surveillance practice, beginning the cycle again. As the next section explores, nonintervention can also facilitate the creation of anti-privacy norms by ceding norm development to private entities with business models built on data extraction.

\section{Informational Capitalism and Anti-Privacy Norms}

Courts' absence from the social construction of new technologies amplifies designers' power to set sociotechnical norms. Design can influence, nudge, and predetermine our disclosure behavior by triggering the heuristics we use to make decisions. ${ }^{220}$ When design makes things easier to do (like disclosing personal information), we do more of it; when design makes things harder to do (like protect our privacy), we do less of it. ${ }^{221}$ Design also expresses values, telling the stories designers want by controlling their technology's "semantic architecture." 222

Design is, in other words, a means of exercising power. ${ }^{223}$ As Woodrow

Olmstead. Id.

219 See Olmstead, 277 U.S. at 473-74 (Brandeis, J., dissenting) (criticizing the majority's rigidity in addressing novel government surveillance under a strict textualist approach).

220 See Daniel Kahneman \& Amos Tversky, Prospect Theory: An Analysis of Decision Under Risk, 47 Econometrica 263 (1979); Woodrow Hartzog, Privacy's Blueprint 26-30 (2018).

221 Clive Thompson, Coders: The Making of a New Tribe and the Remaking of THE WORLD 11 (2019).

222 Mary Flanagan \& Helen Nissenbaum, Values at Play in Digital Games (2014).

${ }^{223}$ As Langdon Winner argued, it is difficult to understand design independent of its coercive capacities and political dynamics. Langdon Winner, Do Artifacts Have Politics?, 109 Daedalus 121 (1980). See also, e.g., Mary Flanagan et al., Embodying V alues in Technology: Theory and Practice, in Information Technology and Moral Philosophy 322 (Jeroen van der Hoven \& John Weckert, eds., 2008); Batya Friedman \& David G. Hendry, Value Sensitive Design: Shaping Technology With Moral Imagination (2019); Julie E. Cohen, Cyberspace As/And Space, 107 Colum. L. REV. 210, 223 (2007); Joel R. Reidenberg, Lex Informatica: The Formulation of Information Policy Rules Through Technology, 76 TEX. L. REV. 553, 
Hartzog notes, "[t] he realities of technology at scale mean that the services we use must necessarily be built in a way that constrains our choices." ${ }^{224} \mathrm{We}$ can only click on the buttons or select the options presented to us; we can only opt-out of the options from which a website allows us to opt-out.

The power of design is generally leveraged to increase data collection, use, and processing. That is what "informational capitalism" refers to: a political economy where data equals profit. ${ }^{225}$ Scholars have argued that this need for data stems from the marketing industry's quest to better predict consumer responses to advertisements. With the popularization of the World Wide Web, marketers sliced and diced populations into as many latent characteristics as possible so as to better "understand" what consumers want. ${ }^{226}$ Likewise, it is in the economic interests of tech industry executives to guide the design process toward surveillance. Executives at public companies also have legal obligations to pursue profits for shareholders, further incenting data extraction. ${ }^{227}$ For their part, many software engineers, a necessarily powerful group because of the position they occupy at the center of design's translation from concept to code, are rarely trained in nor are particularly cognizant of privacy. ${ }^{228}$ The incentives and attitudes of those doing the work of design and those directing the process from the C-Suite prejudice design against privacy from the beginning. We see this throughout the digital ecosystem. Many smartphone apps collect geolocation data for no reason; ${ }^{229}$ interfaces encourage disclosure and frame sharing in a positive light; ${ }^{230}$ so-called "dark patterns" take advantage of our preference for shiny

554-55 (1997).

224 Woodrow Hartzog, The Case Against Idealising Control, 4 Eur. DATA Prot. L. REV. 423, 426 (2018).

225 See COHEN, supra note 23.

226 See Joseph Turow, The Daily You: How the New Advertising Industry Is DEFINING YOUR IDENTITY AND YOUR WORTH (2011); JOSEPH TUROW, BREAKING UP AMERICA: AdVERTISERS AND THE NEW MEDIA WORLD (1998).

${ }^{227}$ Lina Khan \& David E. Pozen, A Skeptical View of Information Fiduciaries, 133 HARV. L. REV. 497 (2019).

228 Ari Ezra Waldman, Designing Without Privacy, 55 Hous. L. REV. 659 (2018).

${ }^{229}$ See, e.g., Tim Sampson, Popular Flashlight App Secretly Collected and Sold Users' Location Data, DAILY DOT (Mar. 2, 2020), https://www.dailydot.com/debug/flashlight-app-collects-sellslocation-data.

${ }^{230}$ Leslie K. John et al., Strangers on a Plane: Context-Dependent Willingness to Divulge Sensitive Information, 37 J. CONSUMER RES. 858 (2011). 
colorful buttons over grey ones; ${ }^{231}$ platforms nudge us to buy products others have bought before us; ${ }^{232}$ and apps gamify sharing by encouraging us to continue a 'streak' with our friends. ${ }^{233}$

In many cases, users have little power to react in ways contrary to or inconsistent with design. ${ }^{234}$ Design, therefore, is a powerful norm generator. As Hartzog explains, "[o]nce design affects our perceptions, it begins to shape our behavior. Once it shapes our behavior, it can be used to control us because it shapes what we perceive as "normal." 235 Therefore, courts that adopt the nonintervention principle leave the arena in which social norms are contested to these powerful forces of design, almost all of which privilege surveillance over privacy.

Technology companies also market their products to encourage sharing. Social platforms promise to "bring people together," but only if users share their likes and dislikes. ${ }^{236}$ Dating apps advertise the most accurate matches, but only if users answer hundreds of intimate questions. ${ }^{237}$ The

231 Dark patterns are design tricks that manipulate us into taking certain actions online. Arunesh Mathur et al., Dark Patterns at Scale: Findings from a Crawl of $11 \mathrm{~K}$ Shopping Websites, 3 Proc. ACM ON HUMAN-COMPUTER INTERACT. 1 (2019).

${ }^{232}$ John Naughton, How Amazon Puts Misinformation at the Top of Your Reading List, THE GUARDIAN, Aug. 8, 2020, https://www.theguardian.com/commentisfree/2020/aug/08/amazon-algorithm-curatedmisinformation-books-data.

233 Jay Peters, A Snapchat-Owned Location App Just Added a Leaderboard Comparing Who Stays Home the Most, THE VERGE, (Mar. 24, 2020), https://www.theverge.com/2020/3/24/21192741/snapchat-zenly-app-stay-at-homeleaderboard-coronavirus-social-distancing (discussing an app that typically encourages users to share their location as much as possible).

${ }^{234}$ Henri LeFebvre, The Production of Space (Donald Nicholson-Smith trans. 1991) (arguing that a space is defined by what designers want to happen or not to happen in it).

235 HARTZOG, supra note 220, at 42.

236 Mark Zuckerberg, Bringing the World Closer Together, FACEBOOK (June 22, 2017), https://www.facebook.com/notes/mark-zuckerberg/bringing-the-world-closer-

together/10154944663901634/. See also Helen A.S. Popkin, Privacy Is Dead on Facebook. Get Over It, NBCNEWS.COM (Jan. 13, 2010), http://www.nbcnews.com/id/34825225/ns/technology_and_science-

tech_and_gadgets/t/privacy-dead-facebook-get-over-it (quoting Facebook's privacy guidance document as stating that "[m]aking connections-finding people you know, learning about people, searching for what people are saying about topics that interest youis at the core of our product. This can only happen when people make their information available and choose to share more openly.").

237 Anabel Pasarow, How to Get More Matches on OkCupid, According to an Expert, REFINERY29 
multibillion-dollar femtech industry collects intimate data on its users and often sells that data to third parties, while marketing its products as enhancing women's health and sexual enjoyment. And artificial intelligence companies market their algorithms with highly dubious claims of predictive accuracy, amplifying their "imperative" to collect data. ${ }^{238}$

This has direct and deleterious effects on the ability of the Fourth Amendment to protect privacy. When courts decline to resolve Fourth Amendment cases on the merits because social norms are in flux, the norms that eventually emerge will not be neutral or organically developed by autonomous actors. Rather, those norms will be shaped by the companies that control product marketing and design, filtered through those companies' profit-maximizing interests. Over time, the process of nonintervention, antiprivacy norm formation, and judicial application of "settled" norms systematically biases social norms against privacy.

We can observe a similar process unfolding in the lower courts. The Supreme Court has not yet weighed in on the privacy expectations, if any, associated with social media accounts such as Facebook. In the absence of clear direction, lower courts addressing the issue "have held that whether the Fourth Amendment applies to a user's Facebook content depends, inter alia, on the user's privacy settings." ${ }^{239}$ In practice, courts have placed a burden of proof on defendants to demonstrate that their privacy settings are rigorous enough to justify Fourth Amendment protection. ${ }^{240}$ This would typically

(May 15, 2019), https://www.refinery29.com/en-us/okcupid-profile-questions-matches. 238 See Danielle Keats Citron, A Poor Mother's Right to Privacy: A Review, 98 B.U. L. REv. 1139, 1141 (2018).

${ }^{239}$ United States v. Westley, No. 3:17-CR-171 (MPS), 2018 WL 3448161, at *6 (D. Conn. July 17, 2018) (quoting United States v. Meregildo, 883 F. Supp. 2d 523, 525 (S.D.N.Y. 2012)) (internal quotation marks omitted). See also United States v. Khan, No. 15-cr-00286, 2017 WL 2362572, at*8 (N.D. Ill. May 31, 2017) (holding that defendant could not claim a Fourth Amendment violation where he did not maintain privacy restrictions on his Facebook account).

240 Westley, 2018 WL 3448161, at *6 ("'There is a spectrum of privacy settings available on Facebook, and those settings can be tailored to specific types of communications...the defendants have done nothing to show what, if any, privacy settings governed any of the types of communications found in their accounts. Defendants have therefore not established that they had a reasonable expectation of privacy in any of the communications described in the affidavits.”); United States v. Devers, No. 12-CR-50-JHP, 2012 WL 12540235, at *2 (N.D. Okla. Dec. 28, 2012) ("[U]nless the defendants can prove that their Facebook accounts contained security settings which prevented anyone from accessing their accounts, this court finds their legitimate expectation of privacy ended when they disseminated posts 
require more than just restricting Facebook posts to one's friends. ${ }^{241}$ But, over the past fifteen years, Facebook has notoriously made it difficult for its users to effectively use their privacy settings or limit the dissemination of their posts. ${ }^{242}$ Facebook's anti-privacy design has thus helped to shape surveillance-relevant practices and norms. And there is little question about Facebook's preferences for norms among its users-Mark Zuckerberg has stated explicitly that keeping personal information private online is no longer the "social norm." ${ }^{243}$ The company has also consistently advanced the legal position that its users have no privacy interests in any information they share with Facebook. ${ }^{244}$ When the Supreme Court eventually weighs in on social media privacy, it will do so in an environment shaped by Facebook and its aggressively anti-privacy design and practices.

\section{Surveillance Creep}

Judicial norm-reliance and nonintervention also facilitate the process of surveillance creep. ${ }^{245}$ Surveillance creep is related to the engineering concept "function creep," where a device designed for one purpose ends up being

to their 'friends' because those 'friends' were free to use the information however they wanted.”)

241 E.g., Palmieri v. United States, 896 F.3d 579, 588 (D.C. Cir. 2018) (holding that the government could obtain information shared with the defendant's Facebook friends); United States v. Meregildo, 883 F. Supp. 2d 523, 525 (S.D.N.Y. 2012) (finding no expectation of privacy in posts sent to a defendant's Facebook friends).

242 E.g., It's Time to Make Our Privacy Tools Easier to Find, https://about.fb.com/news/2018/03/privacy-shortcuts (acknowledging that its privacy settings remain difficult for many users to find);

Complaint, In re Matter of Facebook, https://www.ftc.gov/sites/default/files/documents/cases/2011/11/111129facebookcmp t.pdf, at $\$ 19-29$ (describing how Facebook regularly manipulated and hid its privacy settings to make it difficult or impossible for its users to restrict the dissemination of their information).

243 Bobbie Johnson, Privacy No Longer a Social Norm, Says Facebook Founder, GUARDIAN (Jan. 10, 2010), https://www.theguardian.com/technology/2010/jan/11/facebook-privacy.

244 Transcript of Oral Argument at 7, In re Facebook, Inc. Consumer Privacy User Profile Litigation, 402 F.Supp.3d 767 (N.D. Cal. May 29, 2019) (No. 18-MD-02843); Campbell v. Facebook, Inc., 951 F.3d 1106, 1119 n.9 (9th Cir. 2020); Appellee’s Brief at 21, Smith v. Facebook, Inc., 745 Fed. Appx. 8 (9th Cir. Dec. 18, 2017) (No. 17-16206), https:/ / epic.org/amicus/facebook/smith/Smith-v-Facebook-9th-Cir-Facebook-Brief.pdf. 245 Brett M. Frischmann \& Evan SElinger, Re-EngineEring Humanity 20-21 (2018). 
used for another purpose. ${ }^{246}$ Brett Frischmann and Evan Selinger give the example of a driver's license, which grew from a permission card for drivers to a general form of identification. ${ }^{247}$

Surveillance creep is a form of function creep that involves data collection. It occurs when a device designed for one type of information gathering ends up being used for other, often more invasive types of information gathering. For example, wearable health trackers like FitBit or Apple Watch may have originally been used to count steps, but they can also be deployed by health insurance companies, schools, or workplaces to determine eligibility for discounts, liability for injury, or access to opportunities. Integrating GPS into a mobile dating app can tell users about potential matches near them, but it can also be used to triangulate the precise location of queer people hiding from abusive communities, families, or governments. ${ }^{248}$ And a camera at a four-way intersection may have originally been installed to photograph the license plates of speeders or those who drive through red lights. But once the cameras are in place, it becomes easier for governments to use them to monitor pedestrians using facial recognition technology.

Far from a hypothetical or speculative concern, these kinds of surveillance creep are already here. During anti-racism protests in May and June 2020, police in San Diego used streetlight sensors and cameras, previously installed to capture transit and environmental data, to identify, harass, and prosecute protestors. ${ }^{249}$ And once an isolated security tool, face scans are now being used in place of boarding passes at airports, with the attendant databases of faces providing even more opportunities for surveillance. ${ }^{250}$ Existing tracking tools being repurposed for Covid-related

\footnotetext{
246 Bruce Schneier, Security and Function Creep, 8 IEEE SEC. \& PRIVACY, 88, 88 (2010).

247 FRISCHMANN \& SELINGER, supra note 245, at 20.

248 See, e.g., See, e.g., Rick Noack, Could Using Gay Dating App Grindr Get You Arrested in Egypt?, $\begin{array}{llll}\text { WASH. } & \text { POST } & \text { (Sept. 2014), }\end{array}$ http://www.washingtonpost.com/blogs/worldviews/wp/2014/09/12/could-using-gaydating-app-grindr-get-you-arrested-in-egypt/; Mark Joseph Stern, This Daily Beast Grindr Stunt Is Sleasy, Dangerous, and Wildly Unethical, SLATE (Aug. 11, 2016), https://slate.com/technology/2016/08/the-daily-beasts-olympics-grindr-stunt-isdangerous-and-unethical.html.

${ }^{249}$ Jesse Marx, Police Used Smart Streetlight Footage to Investigate Protesters, VOICE OF SAN DIEGO (June 29, 2020), https:/ / www.voiceofsandiego.org/topics/government/policeused-smart-streetlight-footage-to-investigate-protesters.

${ }^{250}$ Dan Reed, Your Face Is Your Passport: Biometrics Could Enable Explosive Travel Growth, But
} 
contact tracing are another example of ever-expanding surveillance. ${ }^{251}$

Surveillance creep has a subtle yet powerful impact on sociotechnical norms because of its ability to normalize surveillance as ordinary, routine, and expected. Data tracking in schools may offer administrators quantitative metrics on which to evaluate student success, but its use habituates young people to third-party data collection. ${ }^{252}$ The launch of facial recognition cameras in London prepares the ground for "wider public acceptance of a ... rights-hostile technology via a gradual building out process." ${ }^{253}$ GPS technology may be helpful for tourists navigating new cities or to help drivers find the fastest route home, but it also routinizes the experience of other people knowing where you are at all times and adjusts our expectations about others' access to our data. ${ }^{254}$ It is also relatively easy for information age devices to take on new surveillance capabilities: tablets, wearables, mobile apps, and so-called "smart" devices can be updated via wireless uploads in the background while no one is looking. ${ }^{255}$ This contrasts with the significant effort involved in updating industrial age devices; installing a CD player or an airbag or a sunroof in an old car, for example, required a trip to a repair shop, physical deconstruction, and reconstruction. Whereas the obvious effort involved in the latter emphasized the significance of the change, the ease of the former suggests its ordinariness.

By relying on precedents involving older technologies to justify the use of newer, more advanced surveillance, courts unwittingly leverage the normalization effect of surveillance creep in Fourth Amendment cases. For

Critics Fret About Privacy Loss, FORBES (Sept. 19, 2019),

https://www.forbes.com/sites/danielreed/2019/09/19/your-face-is-your-passport-

biometrics-hold-promise-for-enabling-explosive-travel-growth-but-critics-fret-about-

privacy-loss.

251 Andy Greenberg, Does Covid-19 Contact Tracing Pose a Privacy Risk? Your Questions, Answered, WIRED (Apr. 17, 2020), https://www.wired.com/story/apple-google-contact-tracingstrengths-weaknesses.

${ }^{252}$ FRISCHMANN \& SELINGER, supra note 245, at 21.

${ }^{253}$ Natasha Lomas, London's Met Police Switches on Live Facial Recognition, Flying in Face of Human Rights Concerns, TECHCRUNCH (Jan. 24, 2020), https:/ / techcrunch.com/2020/01/24/londons-met-police-switches-on-live-facial-

recognition-flying-in-face-of-human-rights-concerns.

${ }^{254}$ FRISCHMANN \& SELINGER, supra note 245, at 21.

255 These products are "tethered" and, therefore, easy to update. Chris Hoofnagle, Aniket Kesari \& Aaron Perzanowski, The Tethered Economy, 87 GEO. WASH. L. REV. 783, 784 (2019). 
example, in United States v. White, ${ }^{256}$ the Supreme Court ruled that undercover agents could record private conversations inside a suspect's home, relying on prior rulings permitting undercover agents without recording devices to enter a home. ${ }^{257}$ Because the additional intrusion of a recording device was relatively small, there was no reasonable expectation of privacy against it. ${ }^{258}$ Once one form of surveillance got its foot in the door of people's homes, additional surveillance became easier to justify.

In United States $v$. Forrester, ${ }^{259}$ the Ninth Circuit held that government agents could monitor an individual's internet account and capture his email to/from data, the IP addresses of the websites he visited, and the total volume of data sent to his account. ${ }^{260} \mathrm{~A}$ prior case had allowed the police to use a device known as a "pen register" to tap a suspect's phone lines and collect the numbers that he dialed. ${ }^{261}$ Given the legality of telephone pen registers, the government could "install a pen register analogue" to monitor a person's internet traffic without triggering the Fourth Amendment. ${ }^{262}$ The court ignored the substantially greater quantity and intimacy of internet data, ${ }^{263}$ concluding instead that internet users do not reasonably expect privacy in their internet use any more than they do in their telephone use. ${ }^{264}$

In each of these cases, the Court's approval of early forms of surveillance was used to justify the subsequent use of more advanced forms of surveillance. The Court presumed that individuals had accepted surveillance as normal, and then allowed government monitoring to creep one step further.

\footnotetext{
256401 U.S. 745 (1971)

${ }^{257}$ Id. at 751 (citing Hoffa v. United States, 385 U.S. 293, 300-303 (1966)). White confirmed the continuing validity of the outcome of Lopez v. United States, 373 U.S. 427 (1963), which held, under pre-Katz law, that an undercover agent could carry a recording device. Id. at 439 . ${ }^{258} \mathrm{Id}$. at 752 ("[T] $\mathrm{h}$ ere is no persuasive evidence that the difference in this respect between the electronically equipped and the unequipped agent is substantial enough to require discrete constitutional recognition.”).

259512 F.3d 500 (9th Cir. 2008).

${ }^{260} \mathrm{Id}$. at $504-05$.

261 Smith v. Maryland, 442 U.S. 735, 745-46 (1979).

262 Forrester, 512 F.3d at 505.

263 See Matthew J. Tokson, The Content/Envelope Distinction in Internet Law, 50 WM. \& MARY L. REV. 2105, 2149-51 (2009) (describing the revealing nature of internet IP addresses and data volume information). ${ }^{264}$ Forrester, 512 F.3d at 510.
} 


\section{NEW DIRECTIONS FOR LAW AND SOCIAL NORMS}

Courts' reliance on existing norms, and failure to intervene in cases where norms are unsettled, have led to several substantial errors in Fourth Amendment law. That is not to say that norms have no place in Fourth Amendment jurisprudence. But rather than simply adopting existing norms, courts should examine whether those norms are justifiable. And whether courts choose to get involved in the social construction of surveillance technologies or to stay out of the fray, they must do so appreciating the net surveillant effects of nonintervention.

Sociotechnical norms develop in an arena already skewed in favor of surveillance. When courts avoid intervening where norms are in flux, the mechanisms of design and surveillance creep remain in place. It is true that technology companies are not the only institutions involved in the social construction of new technologies. But they are the most powerful: Scholars have shown that individuals are, on average, ill-equipped to resist designedin nudges on their own, ${ }^{265}$ and the community of privacy advocacy organizations are too small and underfunded to match the power of corporate interests. The law's intervention down the line can only do so much, tweaking or adjusting a marginal change even as the wave of prosurveillance norms continue unchallenged. Instead, if the goal is to achieve an equilibrium between privacy and law enforcement needs, sociotechnical norms need a counterweight. ${ }^{266}$

Courts are well-suited to provide this counterweight. Although courts' institutional interests are manifold, ${ }^{267}$ those interests are generally not the same as the data-extractive interests of technology companies. Courts are also capable of stepping back, conceptualizing the balance between law enforcement and liberty, and making a dispassionate decision in keeping with

265 See Kahneman \& Tversky, supra note 220, at 263; DANIEL KAHNEMAN, THINKING FAST AND SLOW (1st ed. 2011).

${ }^{266}$ The quest for equilibrium is not new in Fourth Amendment law. As Orin Kerr has argued, the relationship between law and technology seems to be one of "equilibrium adjustment." Kerr, supra note 24 , at 480 . In practice, acting as a counterweight to the surveillant interests of technology companies involves starting from the baseline that social norms, whether perceived as settled or in flux, are often going to tilt toward disclosure.

267 See, e.g., Diana Kapiszewski, Tactical Balancing: High Court Decision Making on Politically Crucial Cases, 45 L. \& SOC'Y REV. 471, 477-78 (2011) (describing the judiciary's institutional interests as, among other things, protecting judges' power, the scope of judicial review, and push back against encroachment from other branches). 
what Daniel Meltzer once called the "special attributes of the judiciary." 268 And courts are capable of protecting the rights of minority groups that lack sufficient voices in majoritarian politics. ${ }^{269}$ By questioning the appropriateness of "settled" norms and intervening to protect citizens faced with new data-extractive technologies, courts may serve as a valuable counterweight to the anti-privacy interests of governments and technology companies.

In the following sections, we explore new directions for Fourth Amendment law that can help courts to intervene effectively in cases involving new technologies and avoid excessive norm reliance. We first examine the use of alternative Fourth Amendment paradigms that would allow courts to focus on the effects of surveillance rather than existing social norms. In addition, we propose that courts use a modified form of stare decisis in Fourth Amendment cases involving emerging surveillance technologies, a field in which new approaches may be needed more often than in other areas of constitutional law. ${ }^{270}$ Finally, we survey alternative institutional arrangements for regulating government surveillance and consider how legislatures, administrative agencies, and courts might work together to effectively regulate government surveillance.

\section{A. New Fourth Amendment Paradigms}

Courts rely on existing social norms in virtually every aspect of Fourth Amendment law, as they seek objective bases for their rulings on surveillance and policing. Dominant doctrinal paradigms facilitate this reliance on norms. The Katzreasonable expectation of privacy test and the reasonableness-based

268 Daniel J. Meltzer, Deterring Constitutional Violations by Law Enforcement Officials: Plaintiffs and Defendants as Private Attorneys General, 88 ColuM. L. REV. 247, 288 (1988).

269 See Andrew Manuel Crespo, Systemic Facts: Toward Institutional Awareness in Criminal Courts, 129 HARV. L. REV. 2049, 2062-63 (2016). This is particularly important in the Fourth Amendment context, which is part of a criminal justice system that disproportionately burdens Black and brown communities. See, e.g., PAul Butler, ChOKeHold: Policing Black Men (2017); Michelle Alexander, The NeW Jim Crow: MAsS InCARCERAtion IN THE AgE OF COLORBLINDNESS (rev. ed. 2012); BRUCE WESTERN, PUNISHMENT AND INEQUALITY IN AMERICA (2006). For the classic discussion of courts' comparative advantages in adjudicating public law issues, see Abram Chayes, The Role of the Judge in Public Law Litigation, 89 HARV. L. REV. 1281, 1307 (1976).

270 Our argument does not critique the doctrine of stare decisis, generally. That discussion is beyond the scope of this Article. 
standards for investigative stops and non-physical seizures encourage courts to act as armchair sociologists, identifying and analyzing common social practices.

There are, however, alternative paradigms that would largely avoid reliance on social norms. In place of the reasonable expectation of privacy standard for searches, scholars have proposed approaches that are more prescriptive and that focus on the effects of surveillance rather than its social valence. These include tests that overtly balance the chilling effects and psychological harms of surveillance against its benefits, ${ }^{271}$ multi-factor tests that identify constitutionally problematic forms of government observation, ${ }^{272}$ and tests that focus on the intimacy, amount, and cost of a given act of surveillance. ${ }^{273}$ Scholars have also suggested alternative paradigms for Fourth Amendment reasonableness, including graduated tiers of reasonableness that offer a more nuanced approach to different kinds of government surveillance, ${ }^{274}$ or partially randomized searches that reduce police discretion and racial discrimination. ${ }^{275}$

By directly examining the effects or intensity of surveillance, and not just its acceptance by society, these prescriptive approaches can lessen reliance on social norms in Fourth Amendment law. ${ }^{276}$ Prescriptive paradigms for Fourth Amendment searches are also more compatible with

271 Tokson, supra note 65, at 744. See also Ric Simmons, Ending the Zero-Sum Game: How to Increase the Productivity of the Fourth Amendment, 36 HARV. J.L. \& PUB. POL'Y 549, 554 (2013) (providing a general theory of cost-benefit analysis in surveillance regulation).

272 See Susan Freiwald, First Principles of Communications Privacy, 2007 STAN. TECH. L. REV. 3, 61-70 (2007) (discussing factors that make government observation especially worthy of regulation); Stephen E. Henderson, Beyond the (Current) Fourth Amendment: Protecting Third-Party Information, Third Parties, and the Rest of Us Too, 34 PEPP. L. REV. 975, 985-1014 (2007) (listing considerations that lower courts have found relevant to privacy). See also Joel R. Reidenberg, Privacy in Public, 69 U. MiAmi L. REV. 141, 155-57 (2014) (proposing a normative regime based on whether surveilled behavior is of private or public concern).

273 Tokson, supra note 88 , at 4.

274 See Christopher Slobogin, Privacy at Risk: The NeW Government SurVeIllanCE AND THE FOURTH AMENDMENT (2007); Alan Rozenshtein, Fourth Amendment Reasonableness After Carpenter, 128 YALE L.J. F. 943, 952 (2019).

275 Bernard E. Harcourt \& Tracey L. Meares, Randomization and the Fourth Amendment, 78 U. CHI. L. REV. 809, 811 (2011).

276 Tokson, supra note 65, at 758-69 (examining the chilling effects of surveillance on activities, its harm to relationships, and direct psychological harms caused by observation); Freiwald, supra note 272, at 61-70 (examining the hidden, intrusive, indiscriminate, and continuous nature of surveillance). 
early judicial interventions addressing new surveillance technologies, because they are more adaptable to rapidly changing circumstances. ${ }^{277}$ Moreover, many of these paradigms can help courts better address surveillance creep. ${ }^{278}$ Rather than relying on sociotechnical norms, these paradigms focus on the broader impacts of government surveillance activities. As such, whether a surveillance practice uses familiar infrastructure matters less under these approaches than under norm-reliant paradigms. ${ }^{279}$ These approaches can accordingly help avoid the normalizing effects of incremental surveillance expansion.

In addition, courts adopting prescriptive approaches to Fourth Amendment law can take the possibility of surveillance creep into account when assessing a new surveillance technology. If a new technology establishes a surveillance infrastructure that could easily be used for additional types of information gathering, that should weigh in favor of stronger Fourth Amendment regulation of the technology. ${ }^{280}$ For example, if license plate reading cameras, which may not themselves capture very sensitive data, could be repurposed to collect facial recognition data or infrared scans of car interiors, that should be a factor in a court's decision to approve the cameras. Because additional uses of existing infrastructure are difficult to monitor, courts may be more effective at limiting the development of pervasive surveillance infrastructure in the first instance. ${ }^{281}$

Of course, these types of forward-looking assessments of surveillance

277 See, e.g., Tokson, supra note 65, at 779-80 (describing the ability of a normative balancing approach to accommodate novel surveillance technologies without being disrupted in the manner of property tests or the reasonable expectation of privacy test). Historical and textbased approaches to Fourth Amendment search law may also avoid reliance on social norms, albeit at the cost of substantially underprotecting privacy and security relative to existing law. See, e.g., id. at 798-801.

278 See supra Part III.C These paradigms include prescriptive balancing tests of harms and benefits, multi-factor tests geared towards assessing new technologies, and graduated tiers of reasonableness. See supra notes 271-275.

279 See supra notes 253-264, 276 and accompanying text.

280 Such an approach would embody the spirit of Justice Brandeis's famous dissent in Olmstead $v$. United States, where he reminded the Court that "in the application of a Constitution, our contemplation cannot be only of what has been, but of what may be." 277 U.S. at 471 (Brandeis, J., dissenting) (quoting Weems v. United States, 217 U.S. 349, 373 (1910)).

281 See David C. Gray \& Danielle Keats Citron, The Right to Quantitative Privacy, 98 MinN. L. REV. 62, 72 (2013) (proposing that courts examine surveillance based on its potential rather than the actual information gathered). 
technologies may be difficult for courts, which are often limited in their technical knowledge and institutional capacity for balancing complex factors. ${ }^{282}$ Moreover, the conservative ideological tilt of the federal courts might skew judicial decisions in favor of law enforcement interests. ${ }^{283}$ As we discuss in Part IV.C, another way to proactively address surveillance creep is to explore alternative institutional structures for surveillance regulation.

\section{B. Flexibility and Stare Decisis}

Several current Supreme Court Justices have put forth theories about stare decisis and when it should dictate case outcomes. ${ }^{284}$ While the power of stare decisis to actually bind Justices is contested, ${ }^{285}$ the Court stands by its precedents far more often than it overrules them. ${ }^{286}$ The force of precedent can deter the Justices from questioning prior erroneous decisions, ${ }^{287}$ influence the Court's grants of certiorari, ${ }^{288}$ and shape the cases that litigants appeal to the Court in the first place. ${ }^{289}$

Whatever its general power, stare decisis may be disfavored in certain situations, such as when a prior decision has proven unworkable, ${ }^{290}$ or when individuals are unlikely to rely on a prior decision in allocating resources. ${ }^{291}$ Our analysis above suggests another area in which judges should be especially willing to overturn existing precedents: cases involving surveillance technologies and related social practices. Courts should be willing to intervene when government entities employ a novel technology, even if the

282 See, e.g., Orin S. Kerr, Fourth Amendment and New Technologies: Constitutional Myths and the Case for Caution, 102 MiCH. L. REV. 801, 857-87 (2004); T. Alexander Aleinikoff, Constitutional Law in the Age of Balancing, 96 YALE L.J. 943, 944 (1987).

283 See Daniel Epps \& Ganesh Sitaraman, How to Save the Supreme Court, 129 YALE L.J. 148, 160-63 (2019).

${ }^{284}$ E.g., Nina Varsava, Precedent on Precedent, 168 U. PENN. L. REV. ONLINE (forthcoming 2020); Will Baude, Precedent and Discretion, 2020 Sup. Ct. Rev. (forthcoming).

285 Frederick Schauer, Stare Decisis: Rhetoric and Reality at the Supreme Court, 2018 SUP. CT. REV. 121, 131-32.

286 Baude, supra note 284 , at 4.

${ }^{287} \mathrm{Id}$.

288 Schauer, supra note 285, at 135.

${ }^{289} I d$.

290 See, e.g., Planned Parenthood of Se. Pennsylvania v. Casey, 505 U.S. 833, 854 (1992);

Gamble, 139 S. Ct. at 1983-84 (Thomas, J., concurring).

291 See, e.g., Casey, 505 U.S. at 854; Larry Alexander, Constrained by Precedent, 63 S. CAL. L. REV. 1,13 (1989). 
norms and practices surrounding the technology remain in flux. ${ }^{292}$ But given the possibility of judicial error in such cases, courts should embed flexibility in their Fourth Amendment decisions. ${ }^{293}$ They should recognize that changing technological and social circumstances often necessitate overruling prior cases in this area. ${ }^{294}$

Judicial opinions might explicitly point towards flexibility by stating that their decisions may not apply if certain circumstances change. ${ }^{295}$ But the future of technology and social norm development is difficult to predict. ${ }^{296}$ A better approach might simply be to recognize that judicial precedents involving surveillance technology may require reexamination when circumstances shift or when courts have the benefit of hindsight. ${ }^{297}$ Relatedly, the Supreme Court could facilitate challenges to Fourth Amendment precedents by making clear that a defendant who successfully overturns a precedent will be able to exclude evidence gathered in reliance on the overturned decision. ${ }^{298}$ Limiting the "good faith" exception for officers who

292 See supra Part II.

293 Cf. Kerr, supra note 24, at 539 (discussing the possibility of flexibility in Fourth Amendment law but arguing instead for a practice of nonintervention).

294 Cf. id. at 541-42 (discussing overrulings and the current difficulty of challenging precedents in the Fourth Amendment context).

295 See id. at 541.

${ }^{296}$ One example of a court issuing a tentative, flexible ruling is Kyllo $v$. United States, where the Court noted that its decision might not apply if infrared cameras entered into general public use. 533 U.S. 27, 34 (2001). Kyllo's reliance on social practices to determine the scope of the Fourth Amendment, while reflecting flexibility, also leaves individuals vulnerable to the erosion of constitutional protections if sociotechnical norms trend against homeowner privacy. For the reasons discussed above, see supra Part III, this norm-reliant approach is flawed.

297 The overruling of Olmstead $v$. United States is an example of this phenomenon, as the Supreme Court in 1967 overturned a 1928 decision permitting warrantless wiretapping after several decades of government abuses and widespread monitoring of citizens began to come to light. See Tokson, supra note 217, at 583-84 (describing the FBI's post-Olmstead wiretapping and bugging program). While Katz's recognition of the flawed nature of Olmstead was long delayed, a greater willingness to overturn Fourth Amendment precedents involving surveillance technology might have hastened the overruling of Olmstead and substantially reduced the severe abuses of government surveillance powers under the prior regime. See $i d$. (describing the government's exploitation of information gathered through wiretapping, including monitoring political groups, influencing judicial appointments, threatening civil rights leaders, and coercing members of Congress).

298 The ability of a defendant who successfully gets a precedent overturned at the Supreme Court to suppress evidence unlawfully gathered is ambiguous after Davis v. United States, 564 
rely on existing law may be necessary to incentivize litigants to challenge questionable precedents. ${ }^{299}$

Lower courts, too, should be empowered to take account of changing circumstances or unworkable higher-court decisions in the Fourth Amendment context. Lower courts sometimes apply binding precedents narrowly, shaping the law's application and signaling to appellate courts that a precedent may be erroneous or otherwise flawed. ${ }^{300}$ This "precedential dialogue" should be encouraged in the Fourth Amendment context, where early interventions by higher courts may require revision over time. ${ }^{301}$ Appeals courts can monitor lower court narrowing and use it to identify precedents ripe for reexamination. ${ }^{302}$ They might also encourage experimentation by expressly stating that lower courts will have a role in implementing a new standard or by citing lower court disagreements in opinions overturning prior decisions. ${ }^{303}$ By embedding flexibility in their decisions involving new technologies, courts can intervene to shape sociotechnical norms and prevent unchecked government surveillance while minimizing judicial errors over time.

\section{Alternative Institutional Structures}

A growing body of scholarship argues that new legislative approaches and administrative structures can help courts govern the sprawling surveillance systems of law enforcement. ${ }^{304}$ Daphna Renan has suggested

U.S. 229 (2011). Davis held that a defendant could not suppress evidence obtained under a precedent that was later overturned, because officers had obtained that evidence in good faith reliance on existing law. Id. at 249-50. The Court left open the possibility that the defendant who personally challenged the precedent could obtain suppression of evidence, as a sort of incentive for successfully challenging erroneous precedents. $I d$. at 248 .

299 See id.

300 Richard M. Re, Narrowing Supreme Court Precedent from Below, 104 GEO. L.J. 921, 925-27

(2016); see also Tokson, supra note 66, at 40-41 \& n. 218 (discussing examples of lower courts narrowing or modifying constitutional doctrines).

301 Re, supra note 300, at 927.

${ }^{302} \mathrm{Id}$.

303 See Pearson v. Callahan, 555 U.S. 223, 234-35 (2009) (citing lower court criticism of Saucier v. Katz, 533 U.S. 194 (2001), as a basis for overruling it).

304 Renan, supra note 64, at 1044-45. See also Erin Murphy, The Politics of Privacy in the Criminal Justice System: Information Disclosure, the Fourth Amendment, and Statutory Law Enforcement Exemptions, 111 MICH. L. REV. 485, 534 (2013) (arguing that "an approach of collaborative constitutionality" between the Court and Congress "is necessary to achieve optimal levels 
that an independent administrative agency-like a more robust Privacy and Civil Liberties Board-can make a "programmatic probable cause determination" that situates a given incident of a search or seizure within the wider ecosystem of law enforcement surveillance. ${ }^{305}$ This would allow standardized procedures and built-in expertise, the hallmarks of a functioning administrative state, to put limits on surveillance at the systems stage. Administrative rules can also supplement the judiciary's efforts to nudge sociotechnical norms by adding an additional "point of entry" for lawjudicial review "at the level of program design." 306 This allows the law to use its expressive power not just on a single incident of surveillance, but also on the structures that support it.

To implement this, scholars suggest that courts direct their decisions to policymakers, calling on them to write rules that prevent recurring injustice in addition to speaking directly to police on the ground. ${ }^{307}$ Such a structure could combine the prophylactic rules of cases like Miranda v. Arizona ${ }^{308}$ with broader directives to legislatures to change police procedures, as seen in cases like United States $v$. Wade. ${ }^{309}$ This could represent a sea change in how courts frame their opinions, ${ }^{310}$ and there are epistemic and practical reasons why calling on policymakers to write prescriptive rules might help courts act as counterweights to anti-privacy norms. Agencies may have greater expertise, particularly regarding the whole picture of law enforcement's surveillance systems, than common law courts making one-off decisions every once in a while. ${ }^{311}$ Agencies can also write prescriptive rules and engage in nimble policy experimentation, allowing them to adjust proposals as they observe the downstream consequences of their actions. ${ }^{312}$

for protecting privacy").

${ }^{305}$ Renan, supra note 64, at 1112-114.

${ }^{306} \mathrm{Id}$. at 1092.

307 See John Rappaport, Second Order Regulation of Law Enforcement, 103 CAL. L. REV. 205, 210 11 (2015).

308384 U.S. 436 (1966). As John Rappaport notes, Miranda is a good example of courts speaking both to officers and to policymakers. The decision includes the case's famous prearrest warnings and a call to policymakers to develop procedural safeguards. Rappaport, supra note 307 , at 224-25.

309388 U.S. 218 (1967) (directing legislatures to change suspect line-up procedures).

${ }^{310} I d$. at $216-18$ (describing how the vast majority of criminal procedure cases are directed toward front line officers).

${ }^{311}$ Rappaport, supra note 307, at 232-33.

${ }^{312} I d$. at $234,236$. 
Lawmakers can also shape social norms relevant to privacy by influencing corporate behavior. This is at least one of the goals of the General Data Protection Regulation (GDPR), the European Union's comprehensive data protection law. ${ }^{313}$ It provides EU citizens with a litany of rights to their data, including rights to access, correct, delete, and transport their data, among others. ${ }^{314}$ In addition, the GDPR imposes procedural and compliance obligations on companies as they collect and process data from their customers. Companies have to hire Data Protection Officers (DPOs) to oversee and ensure corporate compliance with the law. ${ }^{315}$ They also have to keep extensive data processing records, which can be requisitioned by regulators during an investigation. ${ }^{316}$ And, in certain circumstances, the GDPR requires regulated organizations to conduct impact assessments about data processing and collection and platform design. ${ }^{317}$ These internal requirements are supposed to give companies a standard protocol for assessing privacy risks. But, as Margot Kaminski suggests, they are also supposed to affect how companies conceptualize their data privacy obligations, nudging them by keeping privacy front of mind during the design and compliance processes. ${ }^{318}$

This form of "collaborative governance" is incomplete. It allows regulated entities to be directly involved in the creation, interpretation, and application of what the law actually requires, undermining the law's ability to achieve its social ends. ${ }^{319}$ Nor are administrative agencies likely to effectively regulate surveillance on their own; agencies can be politicized and subject to regulatory capture. ${ }^{320}$ But agencies need not work alone. An effective system of governance requires agencies, legislatures, and the courts: the former two can write rules while engaged with a systemic review of the criminal justice system, and the latter can apply judicial review to those rules. ${ }^{321}$ This

313 GDPR, supra note 152, arts. 28, 39(1)(b).

314 Id. at arts. 12-23, 39-47.

315 Id. at art. 37-39, 55-56.

316 Id. at art. $30,50-51$.

${ }^{317}$ Id. at art. 35, 53-54.

318 See Kaminski, supra note 157, 1603-05.

319 See Lauren B. Edelman, Working Law: Courts, Corporations, AND Symbolic Civil Rights (2016); Ari Ezra Waldman, Privacy Law's False Promise, 97 Wash. U. L. ReV. 773, 787-88 (2020).

320 See, e.g., RORY V. LOO, The Missing Regulatory State: Monitoring Businesses in an Age of Surveillance, 72 VAND. L. REV. 1563, 1624 (2019).

${ }^{321}$ Renan, supra note 64, at 1125-26. 
collaboration can offer additional means through which regulatory power can counterbalance technologies' designed-in surveillance norms.

\section{CONCLUSION}

Prevailing social norms often determine the direction of Fourth Amendment law. Courts and scholars have lauded norm reliance as judicial humility in the face of rapidly changing technology. This Article has challenged that conventional wisdom in two respects. It has shown that the practice of judicial reliance on social norms is more nuanced than previously understood: courts rely on them when they appear to have settled, but decline to get involved when social norms, particularly those about new surveillance technologies, are still being contested. This Article has also shown how current adjudicative paradigms undermine the promise of the Fourth Amendment. By adopting existing norms without questioning whether they are justifiable, courts have embedded discriminatory concepts in Fourth Amendment law. And nonintervention leaves sociotechnical norms to develop in accordance with the data extractive interests of technology companies. As courts remain on the sidelines, our privacy slips away: we become inured to the perceived normalcy of surveillance practices, and new technologies creep more and more toward surveillance. Whether we can reverse course with new judicial and institutional approaches is an open question. But we can start by understanding the risks of the Fourth Amendment's current relationship with social norms and envisioning a different path. 